\title{
The Influence of ENSO Flavors on Western North Pacific Tropical Cyclone Activity $\mathscr{O}$
}

\author{
CHRISTINA M. PATRICOLA \\ Climate and Ecosystem Sciences Division, Lawrence Berkeley National Laboratory, Berkeley, California
}

SUZANA J. CAMARGO

Lamont-Doherty Earth Observatory, Columbia University, Palisades, New York

PHILIP J. KLOTZBACH

Department of Atmospheric Science, Colorado State University, Fort Collins, Colorado

\author{
R. SARAVANAN
}

Department of Atmospheric Sciences, Texas A\&M University, College Station, Texas

\section{PING CHANG}

Department of Oceanography and Department of Atmospheric Sciences, Texas A\&M University, College Station, Texas, and Physical Oceanography Laboratory/Qingdao Collaborative Innovation Center of Marine Science and Technology, Ocean University of China, Qingdao, China

(Manuscript received 9 October 2017, in final form 29 January 2018)

\begin{abstract}
El Niño-Southern Oscillation (ENSO) is a major source of seasonal western North Pacific (WNP) tropical cyclone (TC) predictability. However, the spatial characteristics of ENSO have changed in recent decades, from warming more typically in the eastern equatorial Pacific during canonical or cold tongue El Niño to warming more typically in the central equatorial Pacific during noncanonical or warm pool El Niño. We investigated the response in basinwide WNP TC activity and spatial clustering of TC tracks to the location and magnitude of El Niño using observations, TC-permitting tropical channel model simulations, and a TC track clustering methodology. We found that simulated western North Pacific TC activity, including accumulated cyclone energy (ACE) and the number of typhoons and intense typhoons, is more effectively enhanced by sea surface temperature warming of the central, compared to the eastern, equatorial Pacific. El Niño also considerably influenced simulated TC tracks regionally, with a decrease in TCs that were generated near the Asian continent and an increase in clusters that were dominated by TC genesis in the southeastern WNP. This response corresponds with the spatial pattern of reduced vertical wind shear and is most effectively driven by central Pacific SST warming. Finally, internal atmospheric variability generated a substantial range in the simulated season total ACE $( \pm 25 \%$ of the median). However, extremely active WNP seasons were linked with El Niño, rather than internal atmospheric variability, in both observations and climate model simulations.
\end{abstract}

\section{Introduction}

El Niño-Southern Oscillation (ENSO) is a coupled atmosphere-ocean mode of interannual tropical Pacific climate variability that provides a major source of

Supplemental information related to this paper is available at the Journals Online website: https://doi.org/10.1175/JCLI-D-17-0678.s1.

Corresponding author: Christina M. Patricola, cmpatricola@lbl.gov seasonal tropical cyclone (TC) predictability in most TC basins including the Atlantic, eastern North Pacific, western North Pacific (WNP), and southwestern Pacific (e.g., Gray 1984; Whitney and Hobgood 1997; Bove et al. 1998; Pielke and Landsea 1999; Nigam and Guan 2011; Smith et al. 2007; Ralph and Gough 2009; Chand et al. 2013; Jin et al. 2014; Jien et al. 2015). In considering basinwide TC statistics, there is an observed positive correlation between ENSO and WNP accumulated cyclone energy (ACE), with more intense and longer-lived 
TCs during El Niño seasons compared to La Niña seasons (Camargo and Sobel 2005). The recent strong 2015 El Niño event experienced high WNP TC activity levels typical of El Niño seasons, falling in the top 5th percentile of observations with eight super typhoons (Camargo 2016). In addition to ENSO-driven changes in TC lifetime and strength, WNP TCs tend to be larger during El Niño than La Niña years (Chan and Yip 2003).

The relationship between ENSO and TC activity displays a spatial pattern within the WNP basin. Genesis locations of TCs in the basin have a southeast (northwest) shift during El Niño (La Niña) years (Chia and Ropelewski 2002). TC activity decreases over the South China Sea and increases over the eastern WNP late in the typhoon season during El Niño years and vice versa during La Niña years (Chan 2000). A probabilistic cluster analysis yields similar relationships between ENSO and spatial patterns of WNP TC tracks (Camargo et al. 2007a,b). Accompanying the ENSO-driven spatial patterns in WNP TC track density are changes in landfall rate, with general reductions in landfall during El Niño, except over Japan and the Korea Peninsula, and increased landfall over China during La Niña (Wu et al. 2004).

Although the relationship between ENSO and WNP TCs has been widely investigated, many studies consider all El Niño events together, regardless of their characteristics. This leaves a major knowledge gap, as it has been recognized in the last decade that the spatial patterns of sea surface temperature (SST) warming can vary substantially between El Niño events. In particular, noncanonical El Niño (also known as central Pacific El Niño, El Niño Modoki, or warm pool El Niño), which is characterized by equatorial central Pacific warming, has been observed more frequently and with increasing intensity in recent decades (Ashok et al. 2007; Guan and Nigam 2008; Kug et al. 2009; Lee and McPhaden 2010). In addition, the intensity and frequency of central Pacific El Niño is projected to increase in the future at the expense of canonical (also known as eastern Pacific or cold tongue) El Niño (Yeh et al. 2009; Kim and Yu 2012).

Given the observed and projected changes in ENSO spatial characteristics, together with the strong dependence on El Niño "flavor" of Atlantic TC suppression and eastern North Pacific TC enhancement (Patricola et al. 2016), it is important to understand how El Niño's flavors influence the basinwide statistics and spatial patterns of WNP TCs. However, using an observational record that is relatively short and subsampled by different flavors of El Niño can suggest misleading links between ENSO and Atlantic TCs, owing to the small sample size together with internal atmospheric variability (Patricola et al. 2016, and references therein). A short record can lead to different conclusions in observational studies depending on the dataset and definition of ENSO considered. This is especially the case when studies further divide ENSO types according to temporal evolution (Kim et al. 2016) or rainfall impacts (Wang and Wang 2013).

This paper will focus on these questions: 1) How do the spatial characteristics and intensity of ENSO influence basinwide seasonal TC activity in the western North Pacific, and through what mechanisms? 2) How are the spatial characteristics of WNP TC tracks changed by ENSO flavors? This investigation uses largeensemble climate model simulations that address the challenges in using a short observational record that is confounded by concurrent SST variability unrelated to ENSO. We compare simulated TC activity with an observational analysis that is an update from Wang et al. (2013) to include 2010-15. In addition, a sophisticated clustering technique is used to quantify ENSO-driven changes in the spatial pattern of WNP TC tracks.

\section{Background}

Here we review observationally based studies that focused on WNP TC activity and ENSO flavors. Whereas these studies are marked by uncertainty associated with small sample sizes as described previously, the model simulations presented in the following sections can be subject to uncertainties associated with model biases and physics parameterizations. Therefore, results that are common to both approaches provide the most robust understanding of this topic.

Chen and Tam (2010) found a distinct response of WNP TC frequency to different ENSO flavors, with observed TC number positively correlated with the ENSO Modoki index and weakly correlated with canonical El Niño, represented by the Niño-3 index. Furthermore, observed WNP TC activity was shifted to the west and conditions were more favorable for landfall, particularly over East Asia, during central Pacific El Niño events (Kim et al. 2011; Zhang et al. 2012). Comparison of TC tracks for both ENSO flavors revealed little difference in boreal summer, but large differences in boreal fall, with TCs recurving northward at a farther westward location near the coastline of East Asia during central Pacific El Niño, explaining the increase in landfall frequency in East Asia (Hong et al. 2011). Using composites of 5-8 observed seasons, Wang et al. (2013) found that although the eastern Pacific El Niño drives a southeastern shift in WNP TC genesis during the peak typhoon season of July-September, there was no significant change in TC genesis during central Pacific El Niño events. On the other hand, Xu and Huang (2015) 
found increases in TC activity over the western and eastern North Pacific in composites of four central Pacific warming years. Using a statistical downscaling technique, the track differences during different El Niño flavors were further linked to differences in lifetime and intensity during the WNP TC season (Zhao 2016), with a higher occurrence of intense typhoons for central Pacific El Niño events (Zhang et al. 2015).

Recent model simulations of the response of WNP TC activity to ENSO were forced with observed SSTs (e.g., Mei et al. 2015; Han et al. 2016) and therefore, like observations, are confounded by non-ENSO oceanic variability. In addition, most climate models have difficulty reproducing the WNP TC response to El Niño flavors (Han et al. 2016). Model biases may contribute to projections of WNP TC tracks that are not robust across models and greenhouse gas emissions scenarios, with some models projecting a northward shift (Wu et al. 2014; Kossin et al. 2016) and other models an eastward shift (Li et al. 2010; Murakami et al. 2011; Yokoi et al. 2013; Mori et al. 2013; Chand et al. 2017) or a combination of both (Zhao and Held 2012; Murakami et al. 2012; Colbert et al. 2015; Roberts et al. 2015; Nakamura et al. 2017). The differences among projections make understanding the response of WNP TCs to ENSO's spatial patterns even more critical.

\section{Data and methodology}

\section{a. Observational data}

TC data were taken from the Joint Typhoon Warning Center (JTWC) dataset as archived in the International Best Track Archive for Climate Stewardship, version 03r09 (Knapp et al. 2010). The JTWC maintains the only dataset that has wind data for all WNP TCs back to 1950 . While the observational platforms underpinning this dataset have changed considerably since 1950 (Chu et al. 2002), compositing over a large number of years should help to ameliorate any observationally generated biases.

Tropical Pacific SST data were obtained from the National Oceanic and Atmospheric Administration's (NOAA) Climate Prediction Center for the 1950-2015 period. This dataset calculates SST anomalies in several regions using the NOAA Extended Reconstructed SST, version 4 (Huang et al. 2015). We examined SSTs in three boxes frequently used to assess the strength of ENSO events: Niño- $4\left(5^{\circ} \mathrm{S}-5^{\circ} \mathrm{N}, 150^{\circ} \mathrm{E}-150^{\circ} \mathrm{W}\right)$, Niño$3.4\left(5^{\circ} \mathrm{S}-5^{\circ} \mathrm{N}, 170^{\circ}-120^{\circ} \mathrm{W}\right)$, and Niño-3 $\left(5^{\circ} \mathrm{S}-5^{\circ} \mathrm{N}\right.$, $\left.150^{\circ}-90^{\circ} \mathrm{W}\right)$.

Many different approaches have been used to separate El Niño events into eastern Pacific and central $\mathrm{Pa}-$ cific types (e.g., Ashok et al. 2007; Guan and Nigam
TABLE 1. List of WNP typhoon seasons over the 1950-2011 period classified as CT El Niño, WP El Niño, neutral ENSO, and La Niña, based on August-October averaged Niño-3, Niño-3.4, and Niño-4 indices as described in section $3 \mathrm{a}$.

\begin{tabular}{ll}
\hline \hline CT El Niño & $1965,1972,1976,1982,1987$, and 1997 \\
WP El Niño & $1986,1991,1994,2001,2002$, and 2004 \\
La Niña & $1954,1955,1964,1973,1975,1988$, and 2010 \\
\hline
\end{tabular}

2008; Kao and Yu 2009; Takahashi et al. 2011; Patricola et al. 2016). In the remainder of this manuscript, we follow the physically based nomenclature of Kug et al. (2009) and Patricola et al. (2016) and refer to eastern Pacific El Niño as cold tongue (CT) El Niño and central Pacific El Niño as warm pool (WP) El Niño. We first performed the observational analysis by defining ENSO events in the same way as for the model simulations [described in Patricola et al. (2016, 2017)]. CT and WP El Niño events were defined as the strongest $10 \%$ of observed events based on the August-October averaged Niño-3 index and Niño-4 index, respectively, during the 1950-2011 period (Table 1). Events defined as CT El Niño were excluded from the set of WP El Niño events. Similarly, La Niña is based on the strongest $10 \%$ of negative August-October averaged Niño-3.4 index occurrences.

Since the first method of defining ENSO events produced small sample sizes (six for each El Niño flavor and seven for La Niña), we recalculated the observational analysis using a more relaxed event definition that allows for slightly larger sample sizes. In the second sensitivity analysis, we calculated anomalies over JulyOctober, as over $70 \%$ of typhoons occurred during this period. The 1950-2015 period was included in the analysis, and anomalies were calculated from the 19812010 base period. If the July-October SST anomaly in the Niño-3 region exceeded $0.7^{\circ} \mathrm{C}$ and was greater than the Niño-4 region, it was classified as a CT El Niño event. If the SST anomaly in the Niño-4 region exceeded $0.2^{\circ} \mathrm{C}$ and exceeded that in the Niño-3 region, it was classified as a WP El Niño event, provided the Niño-3 region was also $>0^{\circ} \mathrm{C}$. If the Niño-3 SST anomaly was less than $-0.7^{\circ} \mathrm{C}$, it was classified as La Niña, while all other years were classified as neutral ENSO. Table S1 in the supplemental material displays the years that met each classification, while Fig. S1 therein displays the SST composites for each ENSO type. Of the 66 years studied (covering 1950-2015), 8 were classified as CT El Niño, 8 as WP El Niño, 30 as neutral ENSO, and 20 as La Niña.

\section{b. Regional climate model and simulations}

We conducted simulations with the Weather Research and Forecasting (WRF) Model (Skamarock et al. 2008) 


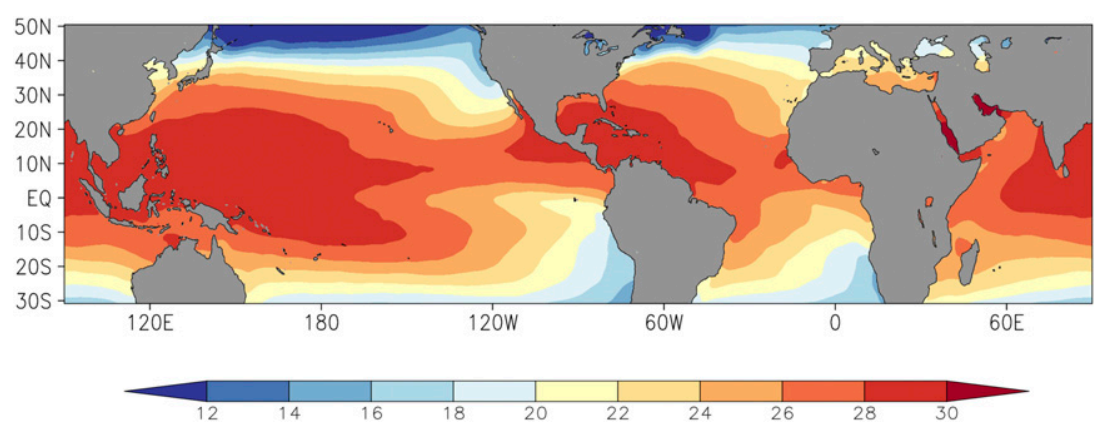

FIG. 1. August-October averaged SST $\left({ }^{\circ} \mathrm{C}\right)$ from the climatology simulation on the TCM domain. Land is shaded gray.

configured as a tropical channel model (TCM), as in Patricola et al. $(2016,2017)$. The TCM uses a TCpermitting horizontal resolution of $27 \mathrm{~km}$ and covers a model domain (Fig. 1) that extends around the globe from $30^{\circ} \mathrm{S}$ to $50^{\circ} \mathrm{N}$, allowing atmospheric disturbances to propagate throughout the tropics and part of the northern midlatitudes.

Five mechanistic experiments (Table 2) were performed with prescribed SST derived from the $1.0^{\circ} \times 1.0^{\circ}$ resolution Met Office Hadley Centre Sea Ice and SST dataset (HadISST; Rayner et al. 2003). The control or "climatology" simulation used the monthly SST climatology from 1950-2011, and is the same control simulation as in Patricola et al. (2016). The August-October averaged SST (Fig. 1) shows the cold tongue and warm pool in the eastern and western equatorial Pacific, respectively.

Four ENSO simulations, representing La Niña and cold tongue, warm pool, and doubled warm pool El Niño, were conducted by adding a SST anomaly characteristic of each ENSO phase to the SST of the climatology simulation. We created the ENSO forcings in an idealized way, since our main focus is to understand the impact of spatial patterns of ENSO on TC activity. Specifically, CT El Niño, WP El Niño, and La Niña forcings (Fig. 2) were constructed according to the strongest $10 \%$ of observed events based on the AugustOctober averaged Niño-3, Niño-4, and Niño-3.4 indices during the 1950-2011 period, as described in the previous section and Patricola et al. $(2016,2017)$. The correlation between August-October averaged Niño-3 and Niño-4 indices is high $(r=0.82)$, as the flavors of El Niño may not represent fundamentally different phenomena (Takahashi et al. 2011), an important subject separate from this study. We also constructed an idealized "doubled warm pool" SST forcing, which is a doubling of the warm pool El Niño forcing based on the strongest $10 \%$ of observed events, and is investigated because the intensity of WP El Niño has approximately doubled in recent decades (Lee and McPhaden 2010). Only tropical-subtropical SST anomalies significant at the 5\% level were included in the ENSO forcings. By constructing the SST forcings this way, the ENSO patterns were isolated from sources of SST variability in other basins, for example, the Atlantic multidecadal oscillation (AMO) (Kerr 2000). In each of the ENSO simulations, constant-in-time SST forcings (Fig. 2) were added to the monthly varying SST of the climatology simulation throughout the entire integration. We note that the simulations deviate from reality in that they do not account for the temporal evolution of ENSO, which intensifies in the latter half of the typhoon season. In addition, the extratropical SST footprints commonly generated by coupled atmosphere-ocean interactions associated with ENSO were not included in our uncoupled atmospheric model simulations.

An ensemble size of 16 and 22 was performed for the La Niña and each of the three El Niño experiments, respectively, in order to quantify internal atmospheric variability and evaluate statistical significance. (The results are insensitive to whether an ensemble size of 16 or 22 members was used for the El Niño experiments.) The ensemble members were generated by initializing the model with different atmospheric states from the National Centers for Environmental Prediction (NCEP)U.S. Department of Energy (DOE) AMIP-II reanalysis (Kanamitsu et al. 2002). Specifically, we started the simulations on 15, 16, 18, 20, 22, 25, 28, and 30 April of 1989 and 1996 and, for all experiments except the La Niña simulation, on 15, 20, 24, 27, 30, and 31 March 1996. Northern and southern lateral boundary conditions (LBCs) are from the 6-hourly NCEP-DOE AMIP-II reanalysis for the corresponding year, 1989 or 1996. These years were chosen so that the LBCs were not strongly affected by midlatitude climate modes near the northern model edge, as 1989 and 1996 were characterized by a relatively neutral Atlantic multidecadal oscillation and Pacific decadal oscillation (Mantua et al. 1997). 
TABLE 2. List of simulations with prescribed SST and ensemble-averaged seasonal total (1 June-30 November) ACE $\left(10^{4} \mathrm{kt}^{2}\right)$ and number of TCs, typhoons (TYs), and intense typhoons (ITYs) over the WNP. The percentage change between the ENSO experiments and the climatology simulation are in parentheses. The ensemble-averaged ACE, TC, TY, and ITY of the ENSO simulations are all significantly different ( $5 \%$ level, one-tailed $t$ test) from those of the climatology simulation. The same measures of TC activity are also shown for the 1950-2015 period of observations, for comparison with the climatology TCM simulation.

\begin{tabular}{llcccc}
\hline \hline \multicolumn{1}{c}{ Simulation } & \multicolumn{1}{c}{ SST } & ACE & TC & TY & ITY \\
\hline Climatology & 1950-2011 monthly climatology & 306 & 28.4 & 27.0 & 13.4 \\
CT El Niño & Climatology plus CT El Niño forcing (Fig. 2a) & $351(14 \%)$ & $32.6(15 \%)$ & $32.0(19 \%)$ & $19.0(42 \%)$ \\
WP El Niño & Climatology plus WP El Niño forcing (Fig. 2b) & $357(17 \%)$ & $33.0(16 \%)$ & $32.2(19 \%)$ & $19.2(44 \%)$ \\
Doubled WP El Niño & Climatology plus doubled WP El Niño forcing & $462(51 \%)$ & $43.1(52 \%)$ & $42.8(59 \%)$ & $29.4(120 \%)$ \\
& (Fig. 2c) & $239(-21 \%)$ & $24.1(-15 \%)$ & $22.5(-17 \%)$ & $9.4(-29 \%)$ \\
La Niña & Climatology plus La Niña forcing (Fig. 2d) & 2308 & 25.4 & 16.8 & 9.4 \\
Observations & Observed 1950-2015 & 308 & \\
\hline
\end{tabular}

Results are insensitive to the choice of LBCs. We note that prescribing the LBCs in this way constrains the influence of the extratropics on the tropics and TCs (Alexander et al. 2010; Smirnov and Vimont 2012; Zhang et al. 2016) in order to focus on the impacts of ENSO on TCs. Each simulation covers the main typhoon season from June through November and ends on 1 December.

TCs were identified in the TCM simulations using the algorithm of Walsh (1997), which includes criteria for a sea level pressure minimum, surface wind speed of at least $17 \mathrm{~m} \mathrm{~s}^{-1}$, and a warm core. We quantified TC activity using TC number and ACE $\left(10^{4} \mathrm{kt}^{2} ; 1 \mathrm{kt} \approx\right.$ $0.51 \mathrm{~m} \mathrm{~s}^{-1}$ ), which is defined as the sum of the squares of the 6-hourly maximum sustained wind speed throughout the lifetime of a tropical cyclone (Bell et al. 2000).
Whereas observed TC categories are based on maximum surface wind speed, the simulated categories were estimated using minimum sea level pressure, because of the underrepresentation of intense TCs as categorized by surface wind speed (Patricola et al. 2017). A better representation of TCs in terms of pressure than wind speed is common in climate models (e.g., Roberts et al. 2015; Murakami et al. 2015a). Furthermore, the intensity bias in the modeled TCs should be expected for climate models with a resolution of $27 \mathrm{~km}$ (Camargo and Wing 2016).

The TCM reproduces the climatology of WNP TC activity reasonably well, with an ensemble-averaged season total ACE of 306 in the control simulation, compared with an observed ACE of 308 during the
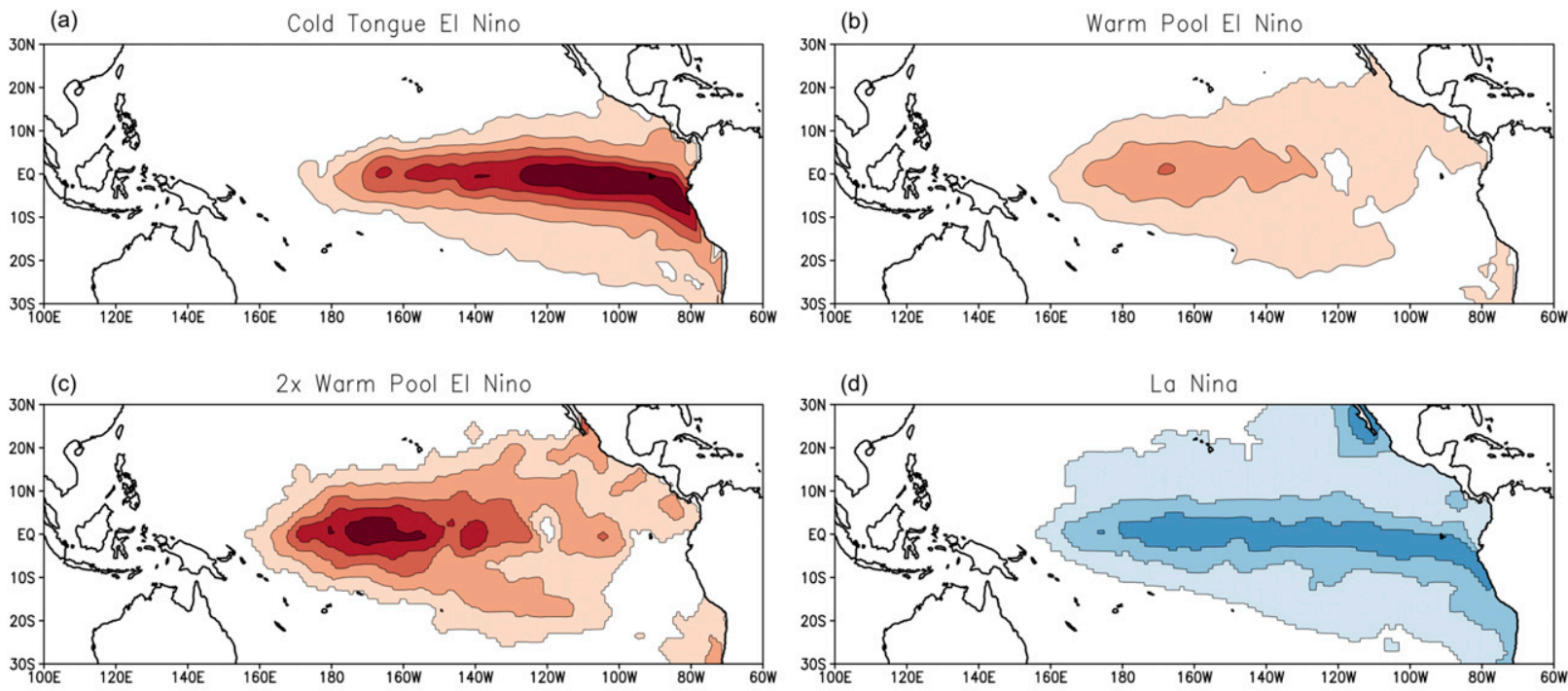

FIG. 2. SST $\left({ }^{\circ} \mathrm{C}\right)$ forcings applied in the TCM simulations representing (a) CT El Niño, (b) WP El Niño, (c) doubled WP El Niño, and (d) La Niña. 


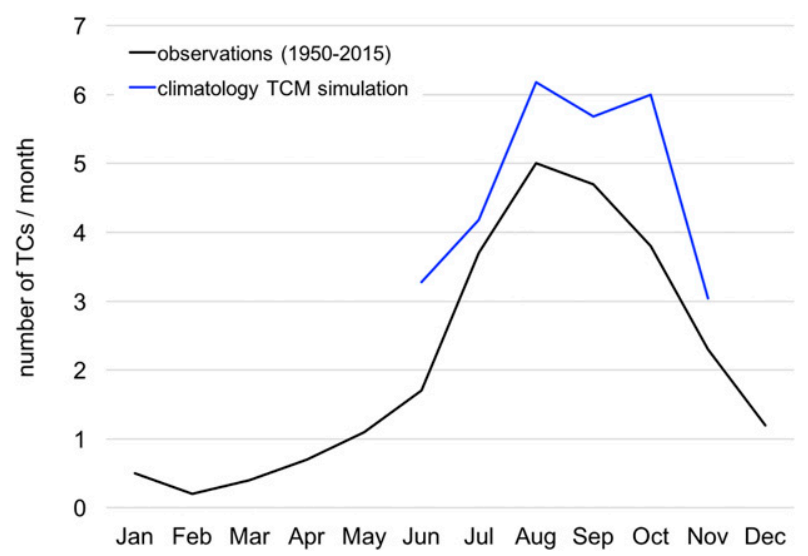

FIG. 3. Average number of TCs generated by month from the 1950-2015 period of observations (black) and the 22-member ensemble of the climatology TCM simulation (blue). The TCM simulation only includes June-November, which includes the observed peak in the typhoon season.

1950-2015 period (Table 2). The TCM slightly overestimates the frequency of WNP TCs, with 28.4 named TCs per year in the climatology simulation and 25.4 observed named TCs per year during 1950-2015 (Table 2). The main model deficiency is in producing too many TCs of typhoon and intense typhoon intensity. In addition, the observed seasonal cycle of TC genesis, including the peak in August, is reasonably represented in the climatology simulation (Fig. 3), with a slight positive bias in the number of simulated TCs present throughout the season.

The spatial patterns of TC track density are similar between the TCM simulations and observations, although the TCM underestimates TCs in the South China Sea relative to the region east of the Philippines (Fig. 4) and generally underestimates the magnitude of the track density. In addition, the TCM is able to reproduce the observed southeastward shift in TC genesis location during El Niño and northwestward shift in genesis during La Niña, despite a westward bias of about $10^{\circ}$ in average longitude of genesis in the climatology simulation (Table 3 ). However, the TCM fails to reproduce the observed increase in TC lifetime in response to El Niño (not shown) demonstrated by Chan and Yip (2003), Camargo and Sobel (2005), and Zheng et al. (2015). This may be related to TC identification criteria that are stricter for the model data than for observations.

\section{c. Cluster methodology}

In our analysis, we used the Gaffney cluster technique (Gaffney 2004). A detailed description of its application to Atlantic extratropical cyclone tracks appeared in Gaffney et al. (2007). This cluster
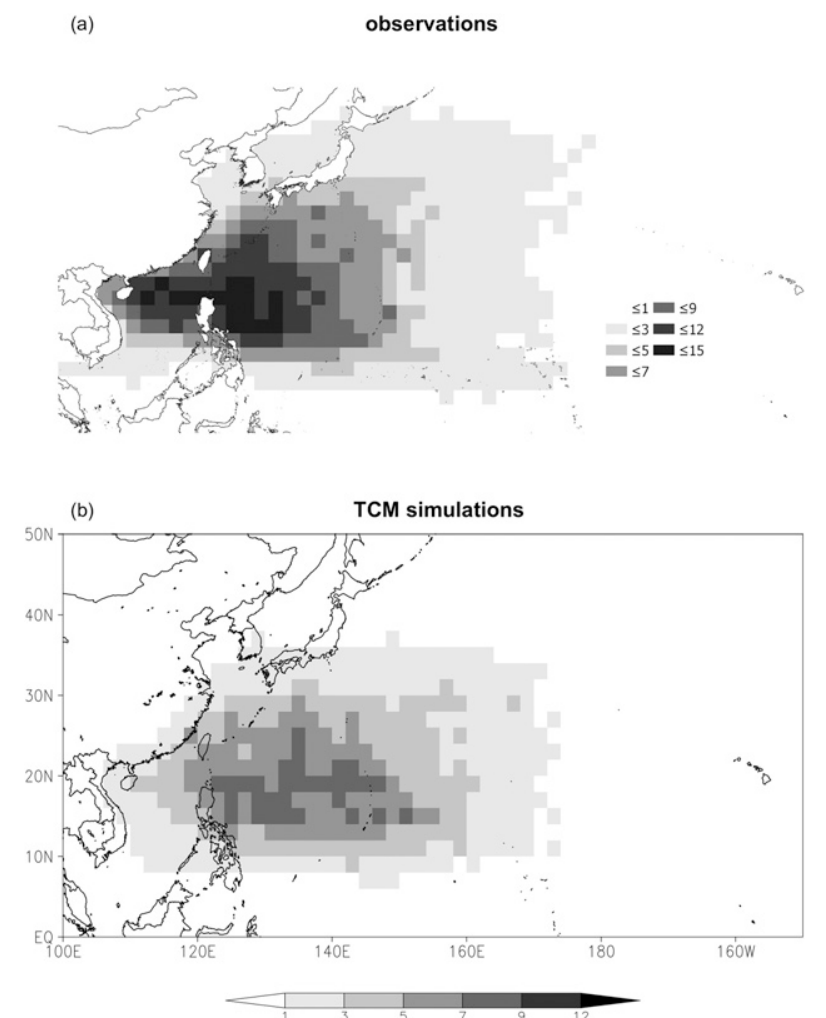

FIG. 4. TC track density from (a) observations during 1950-2015 (No. of TCs per 10 seasons) and (b) the climatology, CT El Niño, and La Niña TCM simulations (No. of TCs per day per 10 seasons), with each of the three experiments given equal weight to normalize for the smaller ensemble size of the La Niña simulation.

technique has been extensively applied to TC tracks for various basins in observations (Camargo et al. 2007a,b, 2008; Kossin et al. 2010; Ramsay et al. 2012; Kozar et al. 2012; Caron et al. 2015; Boudreault et al. 2017), as well as in model simulations (Camargo 2013; Daloz et al. 2015; Nakamura et al. 2017). The cluster technique is based on a mixture of polynomial regression models (quadratic here), which are used to fit the geographical shape of the tracks by maximizing the likelihood of the parameters. The log likelihood can be interpreted as a goodness of fit metric for probabilistic models. One of the advantages of this technique is that it is possible to consider tracks of different lengths, in contrast to other cluster techniques, such as the $K$-means method. Each track is assigned to one of $K$ different regression models, where $K$ is the number of clusters considered. Each model is described by a set of parameters, regression coefficients, and a noise matrix.

First, we updated the cluster analysis of observed western North Pacific TC tracks from the JTWC, which was originally done in Camargo et al. (2007a,b) 
TABLE 3. Average genesis latitude and longitude location from observations and the TCM simulations, with standard deviations in parentheses.

\begin{tabular}{|c|c|c|c|c|c|c|}
\hline & \multirow[b]{2}{*}{ Observations 1950-2015 } & \multicolumn{5}{|c|}{ TCM simulations } \\
\hline & & Climatology & CT El Niño & WP El Niño & Doubled WP El Niño & La Niña \\
\hline Lat & $15.6^{\circ} \mathrm{N}\left(5.7^{\circ}\right)$ & $15.9^{\circ} \mathrm{N}\left(5.7^{\circ}\right)$ & $14.0^{\circ} \mathrm{N}\left(5.7^{\circ}\right)$ & $14.6^{\circ} \mathrm{N}\left(5.6^{\circ}\right)$ & $13.4^{\circ} \mathrm{N}\left(5.5^{\circ}\right)$ & $17.0^{\circ} \mathrm{N}\left(6.1^{\circ}\right)$ \\
\hline Lon & $137.3^{\circ} \mathrm{E}\left(15.3^{\circ}\right)$ & $148.8^{\circ} \mathrm{E}\left(17.2^{\circ}\right)$ & $147.2^{\circ} \mathrm{E}\left(16.9^{\circ}\right)$ & $149.8^{\circ} \mathrm{E}\left(17.7^{\circ}\right)$ & $153.2^{\circ} \mathrm{E}\left(18.4^{\circ}\right)$ & $146.2^{\circ} \mathrm{E}\left(17.4^{\circ}\right)$ \\
\hline
\end{tabular}

for the period 1950-2002. Here we consider the tracks for the period 1950-2015. The same number of clusters $(K=7)$ as in the original analysis was used here. We applied the cluster analysis to the tracks in historical order, and then modified the order of the tracks randomly 100 times and reran the cluster analysis. The final chosen cluster assignment for each track was the one with the smallest absolute value of the loglikelihood among the 101 cases. The clusters were then named A through $\mathrm{G}$ and ordered from the largest to the smallest number of TCs in each cluster, based on the frequency of the original analysis (Camargo et al. 2007a,b) so that it was easier to compare with the original results.

We used a similar procedure for the model tracks, running the cluster analysis 501 times and choosing the case with the minimum absolute value of the loglikelihood as the chosen cluster assignment for each track. Given that the choice of the number of clusters always has some amount of subjectivity [see discussion in Camargo et al. (2007a)], we decided to use the same number of clusters as in the observations $(K=$ 7 ), so that the comparison with observations would be straightforward, as was done in Nakamura et al. (2017). To increase the sample size of the model tracks dataset, we applied the cluster analysis to all model simulations jointly, similar to what was done in other model track analysis (e.g., Camargo 2013; Daloz et al. 2015; Nakamura et al. 2017). It should be emphasized that the only input of the cluster analysis was the latitude and longitude of each trajectory. Consequently, there was no information as to which model simulation the track belongs to. To match the model clusters with the observed ones, we compared the track type and location of the model and observations. Therefore, the model clusters are not necessarily ordered by TC occurrence, as the observed tracks are.

\section{d. Statistical significance in cluster assignments}

To estimate the statistical significance of differences in cluster assignments among the different simulations, we used a Monte Carlo procedure. We randomly assigned each TC to a cluster using two constraints: 1) the total number of TCs in each simulation was fixed, and 2) the total number of TCs in a cluster summed over all simulations was fixed. By using these constraints, we reproduced in our random samples the main characteristics of the cluster distributions across all scenarios. We generated 10000 random cluster assignments and then counted the number of TCs in each cluster and scenario.

We then calculated the probability that the number of TCs across the 10000 random assignments was higher and lower than the actual number of TCs in that cluster and scenario. We repeated the same calculation but used instead of the total number of TCs: 1) the absolute difference in the total number of TCs in each cluster between two scenarios, 2) the percentage of TCs in a cluster and scenario, and 3) the absolute difference in the percentages of TCs in each cluster between the two scenarios. There was a large difference in total number of TCs among the simulations, because of the different forcings, as well as the smaller number of ensemble members in the La Niña simulation. Therefore, we restricted our analysis to the differences in percentages across the scenarios (Table 4) even though the results were robust for all cases, when only the three El Niño scenarios were considered.

\section{Observed influence of ENSO flavors on basinwide TC activity}

We begin by presenting the observed influence of ENSO flavors on WNP TC activity, recognizing the difficulties that can arise in analyzing a relatively short subsampled data record. The analysis here is compared with previous studies, uses a longer dataset that therefore has a greater occurrence of ENSO events, and considers potential sensitivity to ENSO event definition. Table 5 displays the average and standard deviation of TC activity given by ACE and the number of tropical storms, typhoons, and intense typhoons in the WNP based on composites of CT El Niño, WP El Niño, neutral ENSO, and La Niña seasons (defined in Table 1). (Table $\mathrm{S} 2$ in the supplemental material shows the same quantities for the more relaxed event definitions listed in Table S1.) As has been shown in prior work (e.g., Camargo and Sobel 2005), overall TC 
TABLE 4. Differences in the percentages of cluster assignments between TCM simulations, abbreviated as follows: CT El Niño (CT), WP El Niño (WP), doubled WP El Niño (2WP), and climatology (CTL). Boldface indicates differences that are statistically significant.

\begin{tabular}{|c|c|c|c|c|c|c|}
\hline Cluster & $\mathrm{CT}-\mathrm{CTL}$ & $\mathrm{WP}-\mathrm{CTL}$ & $2 \mathrm{WP}-\mathrm{CTL}$ & $\mathrm{WP}-\mathrm{CT}$ & $2 \mathrm{WP}-\mathrm{CT}$ & $2 W P-W P$ \\
\hline A & 0.3 & 1.3 & 1.0 & 1.0 & 0.7 & -0.3 \\
\hline B & 1.4 & -3.2 & -5.1 & -4.6 & -6.5 & -1.9 \\
\hline $\mathrm{C}$ & -8.1 & -3.0 & -5.8 & 5.1 & 2.3 & -2.8 \\
\hline $\mathrm{D}$ & 6.0 & 1.7 & 3.0 & -4.2 & -3.0 & 1.3 \\
\hline $\mathrm{E}$ & 2.4 & 2.0 & 10.8 & -0.4 & 8.4 & 8.8 \\
\hline $\mathrm{F}$ & 3.0 & 0.3 & -4.9 & -2.7 & -7.9 & -5.1 \\
\hline $\mathrm{G}$ & -5.0 & 0.9 & 1.1 & 5.8 & 6.0 & 0.2 \\
\hline
\end{tabular}

activity levels tend to be higher during El Niño events, with more long-lived and intense typhoons compared to La Niña events. Overall, CT El Niño events have comparable or more TC activity than WP El Niño events, with a $35 \%$ and $34 \%$ increase in ACE relative to neutral ENSO events, respectively, and a $35 \%$ and $24 \%$ increase in the number of intense typhoons, respectively. La Niña events have less overall TC activity than either El Niño event type or neutral ENSO conditions, consistent with Camargo and Sobel (2005). The TC responses to ENSO are insensitive to event definition (Tables 5 and S2), with the exception of stronger TC activity for the WP El Niño composite when using the stricter event definition.

The comparable increases in WNP ACE for WP and CT El Niño (Table 5), despite considerably weaker WP El Niño SST anomalies (Fig. 5) are intriguing, and may suggest that warming of the warm pool is more effective at influencing WNP TC activity than warming of the cold tongue, as was the case for TCs in the Atlantic and eastern Pacific (Patricola et al. 2016). The TCM simulations presented in the next section, together with the recent observationally based study of $\mathrm{Wu}$ et al. (2018), provide stronger support for this idea.

Figure 6 shows the maximum lifetime intensity distribution of TCs by Saffir-Simpson wind scale category stratified by ENSO. As would be expected given the overall higher levels of ACE in El Niño events, more intense typhoons (categories 3-5) also tend to occur during El Niño compared with La Niña, as in Camargo and Sobel (2005). Overall, CT El Niño events have the highest number of category 5 intensity typhoons, as was found by Zhang et al. (2015).

\section{Simulated influence of ENSO flavors on basinwide TC activity}

We now present the influence of ENSO flavors on simulated TC activity by first quantifying the ensemble-averaged basinwide TC activity and atmospheric response. In the next section, we extend the analysis to consider the role that internal atmospheric variability plays in driving seasonal WNP TC variability within the context of ENSO. The influence of ENSO flavors on WNP TC tracks and landfall is presented in section 7 .

The simulated TC track density shows a substantial response to ENSO, with decreases over much of the WNP in the La Niña experiment (Fig. 7d). The TC track density response in the El Niño experiments (Figs. 7a-c) is characterized by a swath of increased activity oriented from the southeast to central western portions of the WNP basin, with the greatest magnitude of response in the doubled warm pool El Niño simulation (Fig. 7c) and moderate and weak responses in the CT and WP El Niño simulations, respectively (Figs. 7a and 7b).

These changes in TC track density are accompanied by significant changes in basinwide TC activity. The ensemble-averaged season total WNP ACE and number of TCs are significantly greater (5\% level) in the three El Niño simulations compared with the control simulation, and vice versa for the La Niña simulation (Table 2). The

TABLE 5. Average and standard deviation (in parentheses) of observed WNP number of named storms (NSs), TYs, ITYs, and ACE in composites of CT El Niño, WP El Niño, neutral ENSO, and La Niña typhoon seasons over the 1950-2011 period, as defined in Table 1. The percentage change in activity relative to neutral ENSO seasons is shown for El Niño and La Niña seasons.

\begin{tabular}{lcccccccc}
\hline \hline ENSO type & NS & NS $(\%)$ & TY & TY $(\%)$ & ITY & ITY $(\%)$ & ACE $\left(10^{4} \mathrm{kt}^{2}\right)$ & ACE $(\%)$ \\
\hline CT El Niño & $27.5(3.8)$ & $10 \%$ & $18.8(2.9)$ & $15 \%$ & $12.3(2.1)$ & $35 \%$ & $400(94)$ & $35 \%$ \\
WP El Niño & $28.8(3.5)$ & $15 \%$ & $19.3(1.8)$ & $18 \%$ & $11.3(2.0)$ & $24 \%$ & $396(68)$ & $34 \%$ \\
Neutral ENSO & $25.1(4.6)$ & - & $16.4(3.6)$ & - & $9.1(3.1)$ & - & $296(88)$ & - \\
La Niña & $22.6(7.6)$ & $-10 \%$ & $15.4(5.6)$ & $-6 \%$ & $7.6(3.5)$ & $-16 \%$ & $230(99)$ & $-22 \%$ \\
\hline
\end{tabular}


(a)

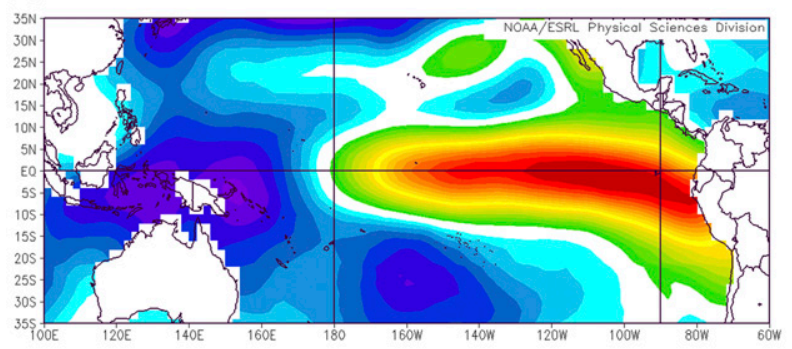

(c)

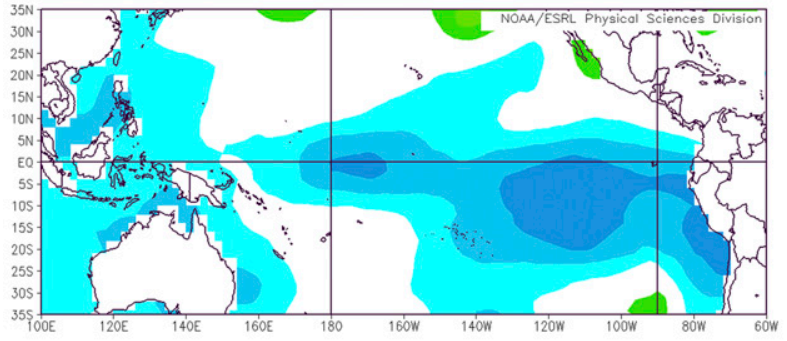

(b)

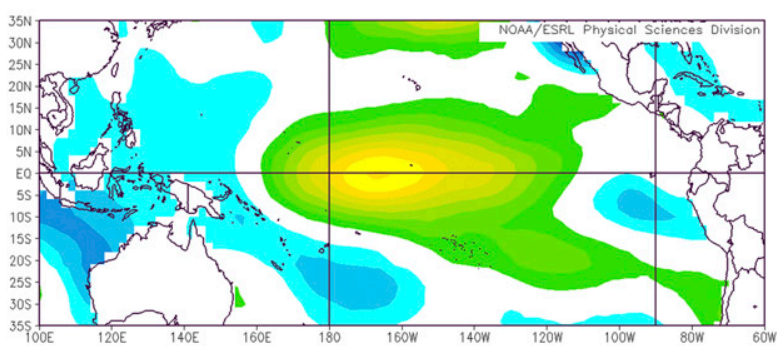

(d)

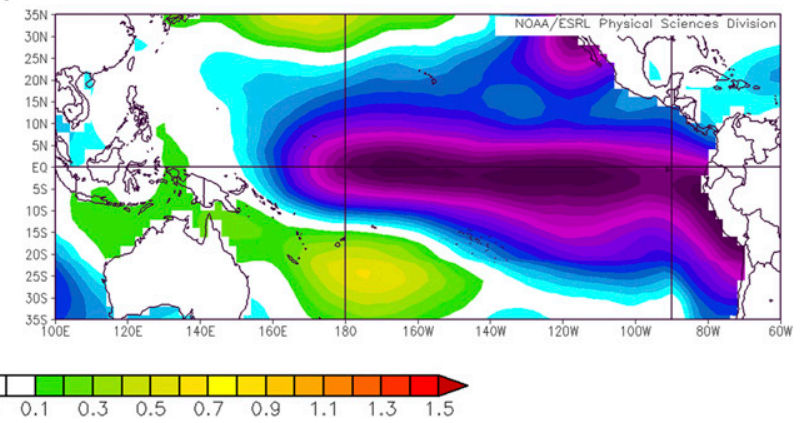

FIG. 5. Observed SST composite anomalies $\left({ }^{\circ} \mathrm{C}\right)$ averaged from August to October for typhoon seasons defined as (a) CT El Niño, (b) WP El Niño, (c) neutral ENSO, and (d) La Niña.

magnitude of the responses is similar between the CT and WP El Niño simulations, with a $14 \%$ and $17 \%$ increase in $\mathrm{ACE}$ and a $42 \%$ and $44 \%$ increase in the number of intense typhoons, respectively. The TCM responses to CT and WP El Niño are more similar in magnitude to each other than in observations for number of intense typhoons, although it is difficult to make an exact comparison as a result of different SST anomalies in the model compared with observations. The response to La Niña is of similar magnitude, but negative, with a $21 \%$ decrease in $\mathrm{ACE}$ and a $29 \%$ decrease in number of intense typhoons. On the other hand, the doubled WP El Niño experiment produces a $51 \%$ increase in ACE and a $120 \%$ increase in the number of intense typhoons, both of which are significantly $(5 \%$ level) greater than the corresponding TC activity in the CT and WP El Niño simulations. This indicates that although CT and WP El Niño corresponding to the strongest $10 \%$ of observed events impact WNP TC activity by similar magnitudes, warming of the warm pool is more effective at enhancing WNP TC activity compared with warming of the cold tongue for similar magnitudes of warming (comparing the $\mathrm{CT}$ and doubled WP El Niño simulations).

A number of physical mechanisms connect ENSO with interannual WNP TC variability. Observed TC genesis location has been linked with changes in vertical wind shear (VWS) between the lower and upper troposphere, the Walker circulation, midtropospheric relative humidity, and the position and strength of the Asian monsoon trough and western Pacific subtropical high, all of which are linked to ENSO (e.g., Chan 1985; Chen et al. 1998; Chia and Ropelewski 2002; Chan 2005; Camargo et al. 2007c). We found that the WNP TC response to ENSO flavors in the TCM simulations is associated with several of these mechanisms.

The TCM produces a response in vertical wind shear to ENSO that is characterized by a complex spatial pattern. The CT El Niño simulation shows increases in VWS in the southwestern portion of the WNP basin and decreases in VWS in the southeastern WNP that almost

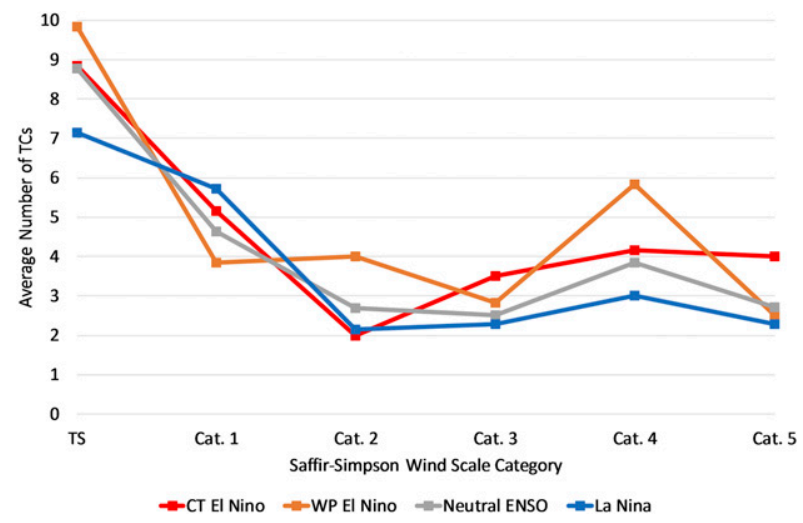

FIG. 6. Observed distribution of maximum intensity of northwestern Pacific TCs binned by Saffir-Simpson wind scale category based on ENSO phase. 

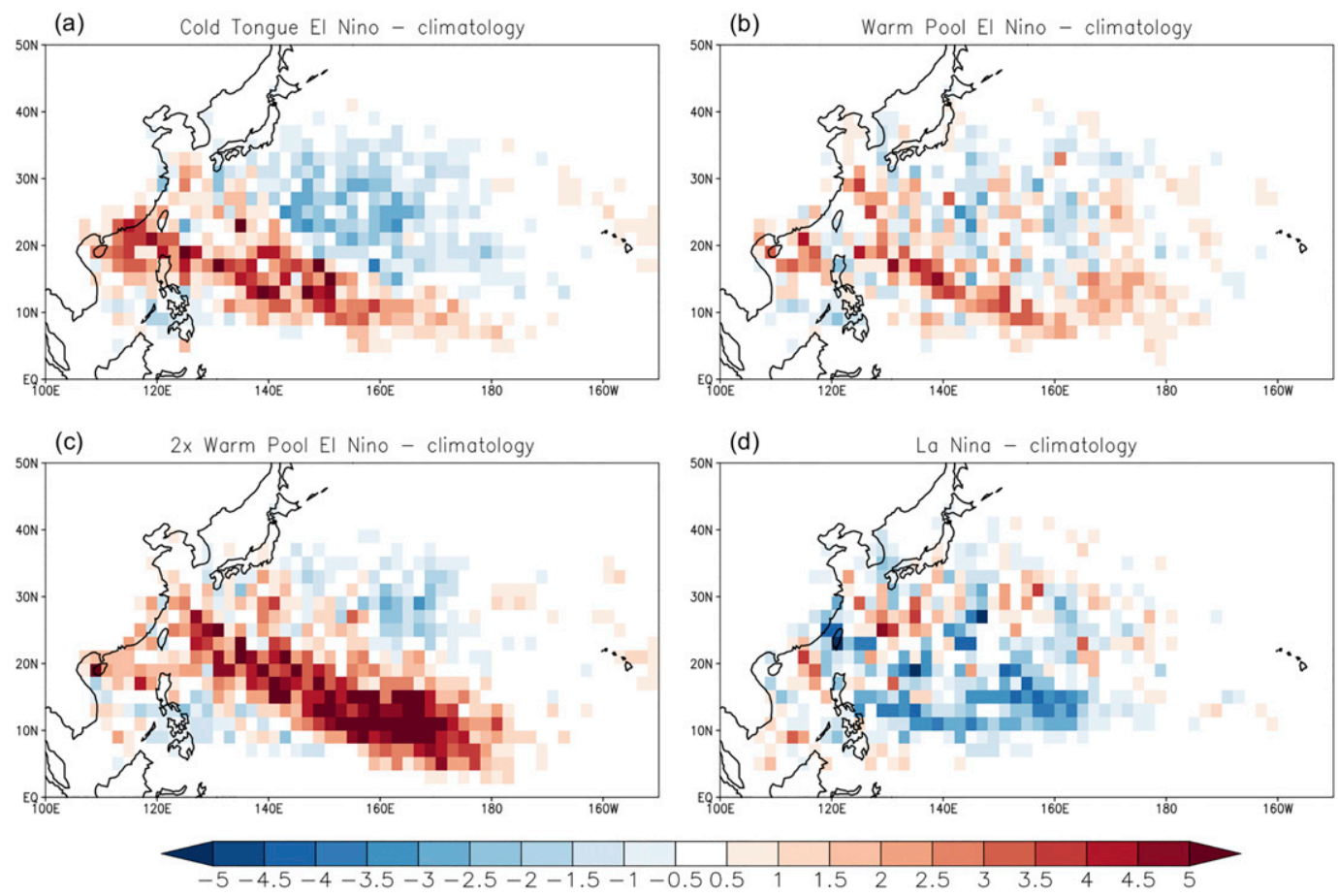

FIG. 7. TC track density (No. of TCs per day per 10 seasons) from the (a) CT El Niño, (b) WP El Niño, (c) doubled WP El Niño, and (d) La Niña simulations minus the climatology simulation.

continuously extend to the region surrounding Taiwan (Fig. 8a). The VWS response is similar but weaker in the WP El Niño simulation (Fig. 8b). The simulated results are comparable with composites of ENSO events from the NCEP-National Center for Atmospheric Research (NCAR) reanalysis (Kalnay et al. 1996) (Figs. 8e,f). Furthermore, the patterns and relative magnitudes of the VWS response to CT and WP El Niño in the TCM simulations are similar to those simulated by $\mathrm{Li}$ and Wang (2014). A new finding here is that the amplitude of the VWS response is greater for an equal magnitude of SST warming in the central Pacific, compared to in the eastern Pacific, as demonstrated by the doubled WP El Niño and CT El Niño simulations, respectively (Figs. 8c and 8a). This is consistent with regional climate model experiments showing that northern off-equatorial central Pacific warming is more effective than equatorial central Pacific warming in inducing changes in the steering flow associated with increased TC activity over East Asia (Jin et al. 2013).

In addition to changes in VWS, increases in midtropospheric relative humidity over the southeastern portion of the WNP and the South China Sea, the Philippines, and Taiwan produce more favorable conditions for TCs in the El Niño simulations (Figs. 9a-c). Again, SST warming near the warm pool (Fig. 9c) is more effective at enhancing relative humidity near the
South China Sea compared with warming of the cold tongue region (Fig. 9a), for similar magnitudes of SST warming. The WP El Niño SST forcing representative of the warmest $10 \%$ of observed cases (Fig. 9b) produces a weaker VWS response compared with the CT El Niño case (Fig. 9a).

\section{Internal atmospheric variability and seasonal predictability}

In the previous section, we demonstrated that La Niña and both flavors of El Niño drive a significant response in ensemble-averaged WNP TC activity. This satisfies one of two criteria needed to gain seasonal TC predictability from skillful ENSO predictions. The second is relatively small internal atmospheric variability, since high predictability requires a low signal-to-noise ratio (i.e., ratio of mean response to internal atmospheric variability). Figure 10 shows box-and-whisker plots of the season total of WNP ACE from the JTWC observations from the full 1950-2011 record and the ENSO composites (as defined in Table 1), and from the 22 ensemble members of the climatology and El Niño simulations and the 16 ensemble members of the $\mathrm{La}$ Niña simulation. Recall that the SST forcing is identical for each TCM simulation within an experiment set, and that ensemble members were generated by varying the 
(a)

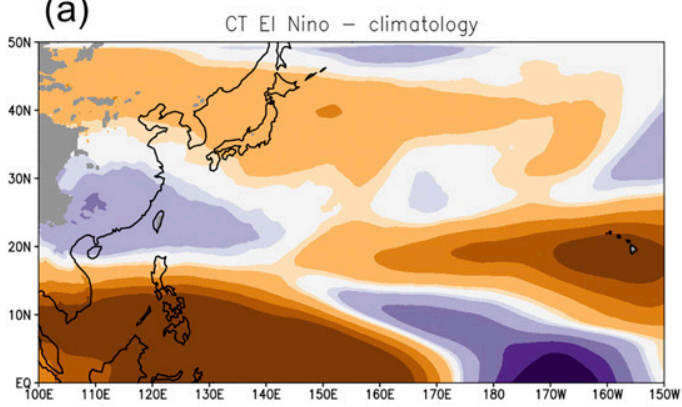

(b)

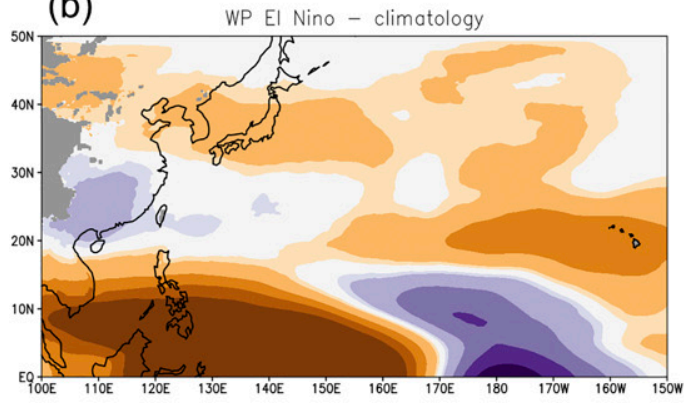

(c)

\section{TCM}

(e)

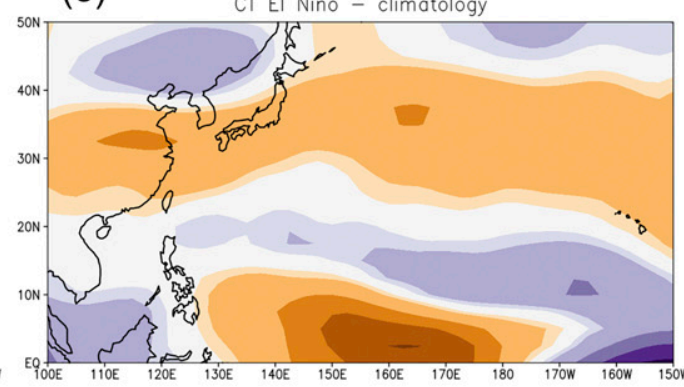

(f)

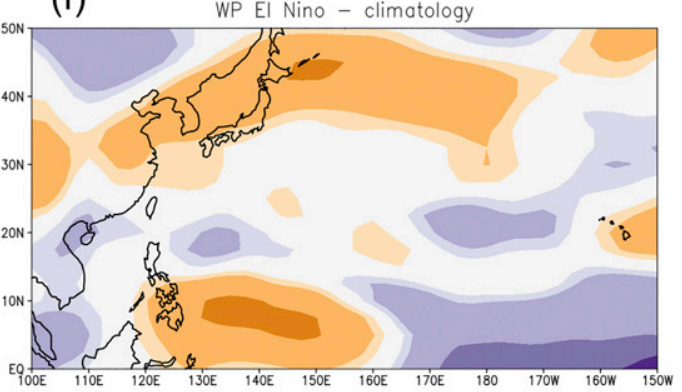

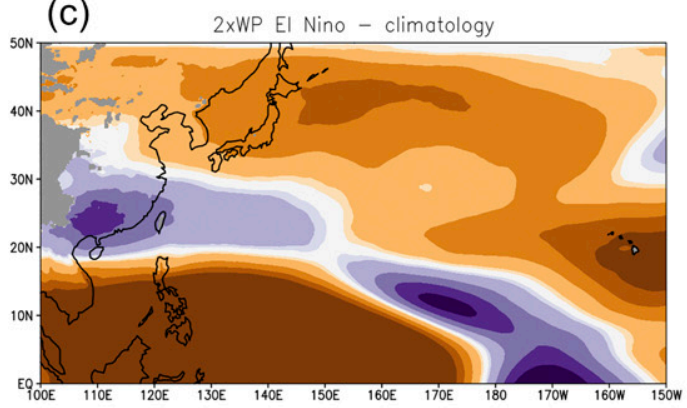

(d)

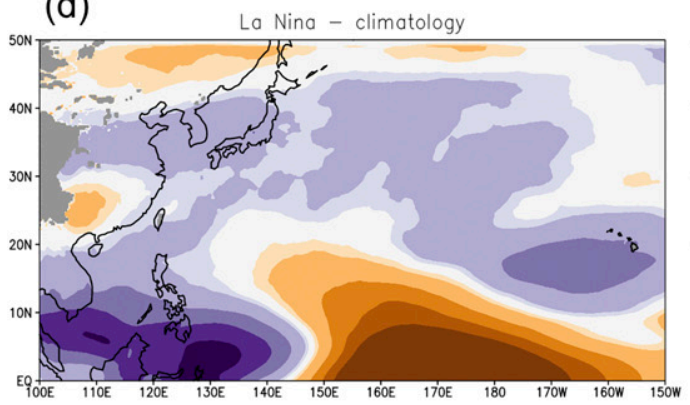

(g)

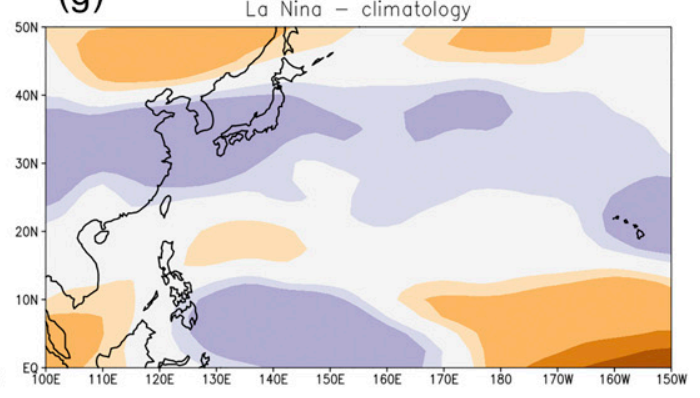

FIG. 8. VWS ( $\mathrm{m} \mathrm{s}^{-1}$ ) between 850 and $200 \mathrm{hPa}$ averaged for July-October from the ensemble average of the (a) CT El Niño, (b) WP El Niño, (c) doubled WP El Niño, and (d) La Niña simulations minus the climatology simulation, and from observed composites of (e) CT El Niño, (f) WP El Niño, and (g) La Niña events minus the 1950-2015 climatology. Land at $850 \mathrm{hPa}$ is shaded gray in (a)-(d).

atmospheric initial conditions, specifically by starting the simulation at a different time. Therefore, the range of TC activity over the full ensemble represents variability that is generated internally by the atmosphere. In comparison, the range represented in the box-and-whisker plots of observations can represent internal atmospheric and oceanic variability, as well as external forcings such as greenhouse gas and aerosol concentrations. 

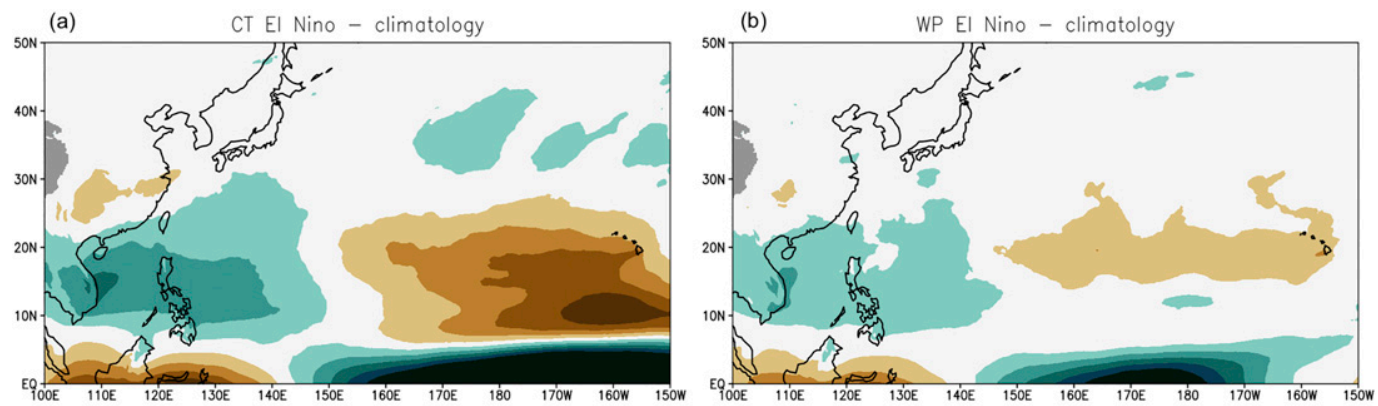

(c) 2xWP El Nino - climatology
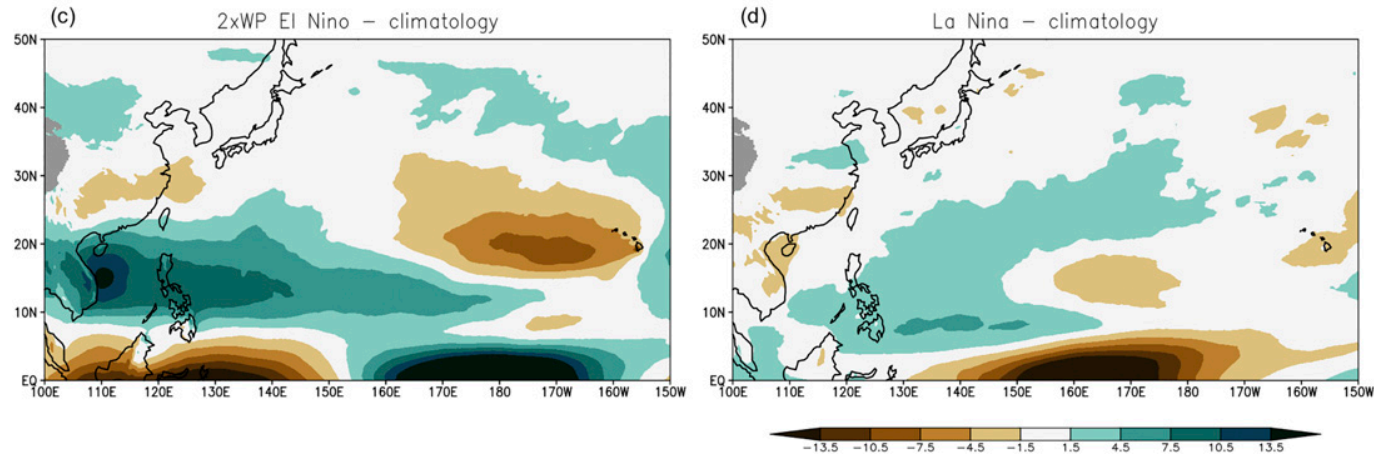

FIG. 9. Relative humidity (\%) at $700 \mathrm{hPa}$ and averaged July-October from the ensemble average of the (a) CT El Niño, (b) WP El Niño, (c) doubled WP El Niño, and (d) La Niña simulations minus the climatology simulation. Land at $700 \mathrm{hPa}$ is shaded gray.

The internal atmospheric variability in the TCM simulations is substantial, with a minimum (228) and maximum (375) season total WNP ACE that is $24 \%$ less than, and $25 \%$ greater than, the median (300) in the climatology simulation (Fig. 10). Despite this range of simulated seasonal TC activity under the same SST conditions, the magnitude of the TC activity response to the ENSO forcings is sufficiently large that there is a noticeable shift in the distributions of ACE. For example, the 25th-75th percentiles of seasonal WNP ACE values in the CT and WP El Niño simulations correspond to the 50th-100th percentile of seasonal ACE values in the climatology simulation. In addition, the 75th-100th percentile of seasonal ACE in the CT and WP El Niño simulations exceeds the maximum value in the climatology simulation. Furthermore, the response in the doubled WP El Niño simulation is so large that the ACE distribution does not overlap with that of the climatology simulation.

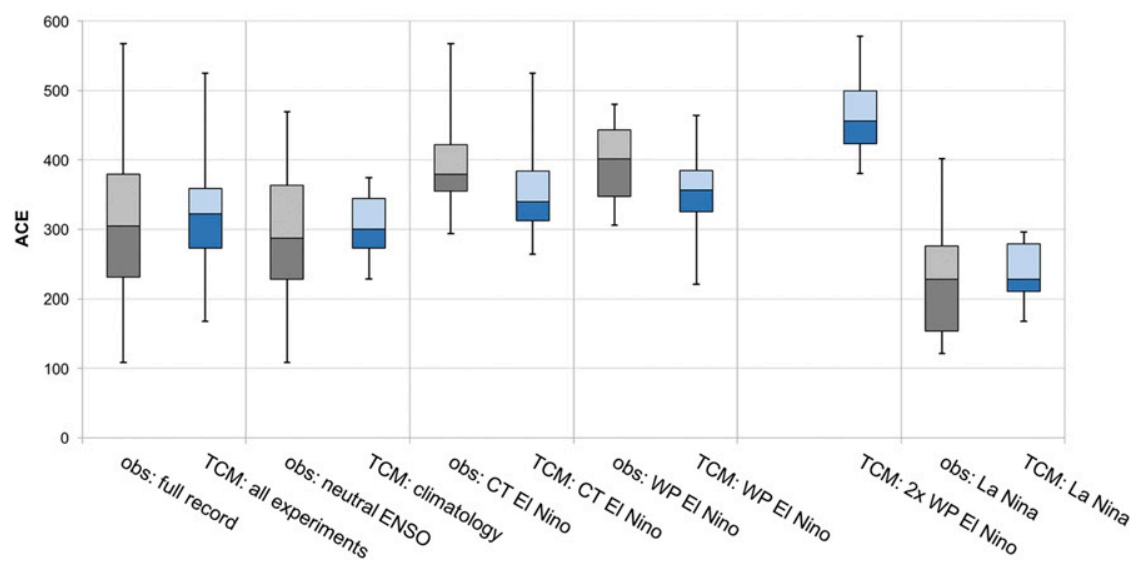

FIG. 10. Box-and-whisker plots of season total WNP ACE, showing the min, the 25th, 50th, and 75th percentiles, and max values, from observations over the 1950-2011 period and for composites according to neutral ENSO, CT El Niño, WP El Niño, and La Niña, as defined in Table 1, (gray) and from the climatology, CT El Niño, WP El Niño, doubled WP El Niño, and La Niña TCM simulations and all experiments (blue). 
Therefore, in addition to confirming what we already knew, namely that ENSO provides seasonal TC predictability in the WNP, this also suggests that central $\mathrm{Pa}$ cific warming provides greater predictability of seasonal WNP TC activity than eastern Pacific warming, for equal magnitudes of warming.

The analysis presented here also indicates that the extremes in seasonal WNP TC activity are driven by SST variability such as ENSO, rather than by internal atmospheric variability. This is suggested by a comparison of the box-and-whisker plots of seasonal ACE between the full set of observations (which include SST variability) and the climatology simulation, in which SST is prescribed according to the monthly varying climatology (i.e., does not contain ENSO variability) (Fig. 10). The climatology simulation only overlaps with the 25 th-75th percentile of the observations. On the other hand, the TCM simulations that were forced with ENSO overlap with portions of the 0th-25th and 75th-100th percentiles of the observations. (We note that the box-and-whisker plots are comparable between the full observational record, and all the TCM experiments considered together, as would be expected if the TCM represents the distribution of seasonal ACE well.) The critical role of SST variability in driving the strongest WNP TC seasons highlights the importance of understanding how changes in ENSO characteristics can influence TC activity. We note that the results are insensitive to using the more relaxed definition of observed ENSO events in Table S1 (see Fig. S2).

We note that the simulated ACE distributions are overall consistent with the observed (Fig. 10). Within each ENSO category, the observations do have a greater range between maximum and minimum values compared with the TCM simulations. This is also the case for neutral ENSO observations and the climatology TCM simulation, which provides the fairest comparison to neutral ENSO conditions in that the anomalous tropical Pacific SST forcing is zero. However, this is to be expected, since the design of the TCM simulations isolates the ENSO-forced signals, whereas the observationally based composites contain other sources of oceanic and atmospheric variability.

\section{TC cluster response to ENSO flavors}

\section{a. Observations}

To examine the regional response of the WNP tracks to ENSO flavors, we used cluster analysis, which can isolate the effect of ENSO on each TC track type. First, however we need to examine how well the model reproduces observed tracks in the WNP. Figure 11 shows the TC tracks in each of the seven clusters, as discussed in detail in Camargo et al. (2007a,b). Here we updated the cluster analysis using observations for the period 1950-2015 (also shown in Nakamura et al. 2017). Figure 12 shows the genesis and landfall locations of each of these clusters. The seven clusters have very different genesis locations and track types and are modulated by climate modes. As discussed in Camargo et al. (2007b), the strongest modulation by ENSO occurs in clusters A, C, E, and G. The most common track type, cluster $\mathrm{A}$, occurs more often during La Niña, as the genesis location in the basin shifts northwestward. In contrast, TCs in clusters $E$ and $G$, which have genesis in the eastern part of the basin, tend to occur much more often during El Niño. These two clusters have a high number of intense typhoons that generate large values of ACE. In the case of cluster C, while there is a significantly higher number of intense typhoons and high values of ACE in El Niño years, the total number of storms is similar for El Niño and La Niña events. SST anomaly composites associated with these clusters (Fig. 9 in Camargo et al. 2007b) show typical La Niña (cluster A), WP El Niño (clusters C and E), and CT El Niño (cluster G) patterns. Note that in the observational analysis there was no attempt to separate between the different ENSO flavors.

\section{b. TCM simulations}

Figure 13 shows the tracks in the TCM climatological simulation also separated by clusters. We matched the model clusters as closely as possible to the observed clusters shown above. It is clear that the model tracks have biases compared with observations. The first notable difference is the lack of occurrences of tropical depression intensities in the model tracks, which is due to the threshold used in the tracking routine in the model tracking algorithm. Second, the model has more difficulty in reproducing recurving track types (clusters A, C, E, and G) than straight moving tracks (clusters B, $\mathrm{D}$, and F). Very few recurving tracks reach north of $40^{\circ} \mathrm{N}$ in the model, which is not the case in observations. This discrepancy could be due to a strict requirement of a warm core storm that is used in the tracking routine for the simulated TCs. The warm core criteria would no longer detect TCs that undergo an extratropical transition (ET), as commonly occurs as TCs reach the midlatitudes. In fact, a larger percentage of storms that reach high latitudes go through ET in the WNP compared with other basins, with the percentage of WNP TCs that undergo ET varying from $27 \%$ to $65 \%$ depending on the observational dataset (Bieli et al. 2018, manuscript submitted to J. Climate). Typical tracking algorithms for TCs simulated in climate models have a warm core requirement (e.g., Walsh 1997; Camargo and Zebiak 2002; Horn et al. 2014) and therefore are not designed to track the TC once it undergoes ET, easily missing this part of the TC tracks. The discrepancy could 
(a) Cluster A - 239 Storms

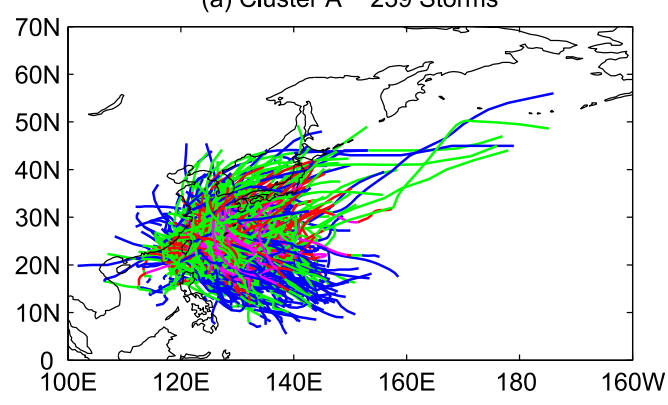

(c) Cluster C - 187 Storms

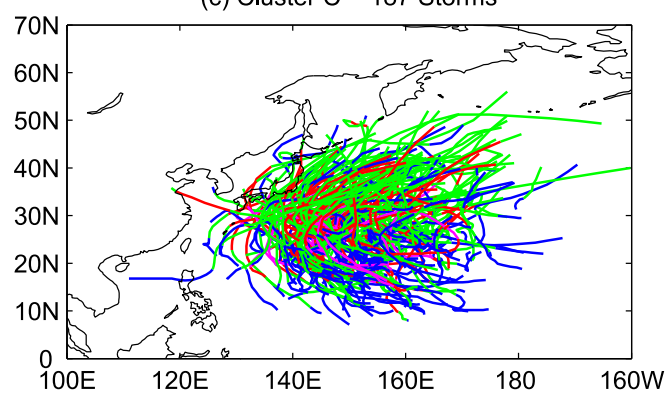

(e) Cluster E - 176 Storms

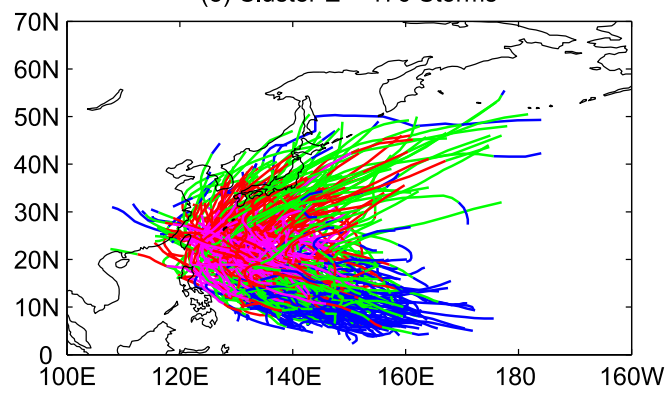

(g) Cluster G - 106 Storms

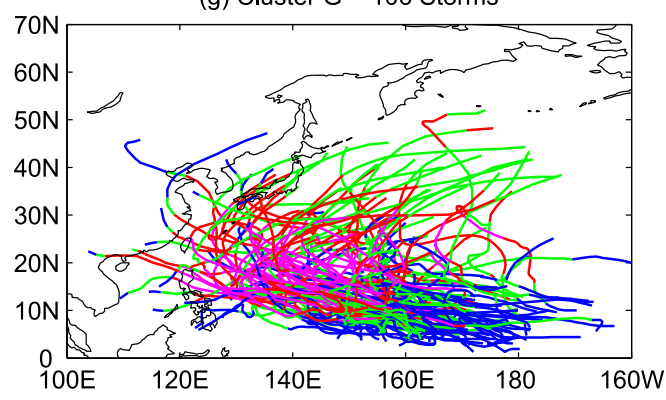

(b) Cluster B - 180 Storms

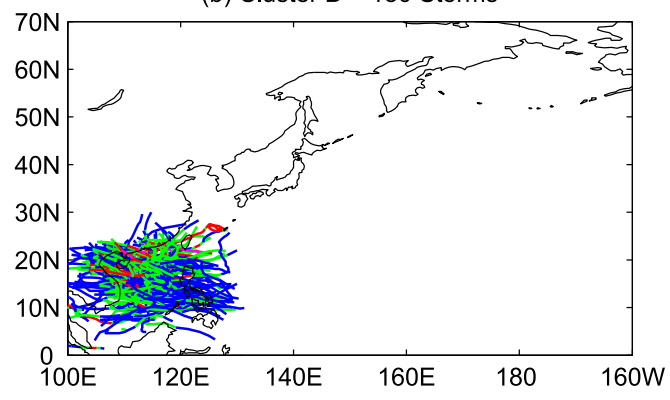

(d) Cluster D - 166 Storms

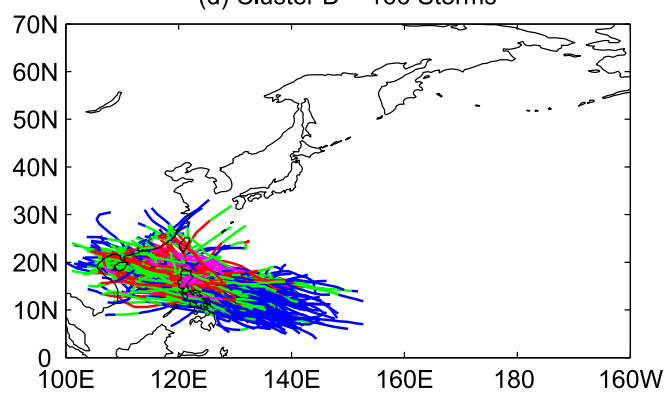

(f) Cluster F - 106 Storms

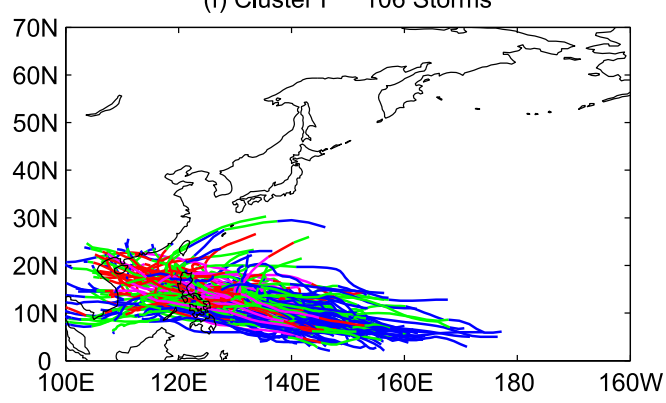

(h) 1160 Storms (1971-2015)

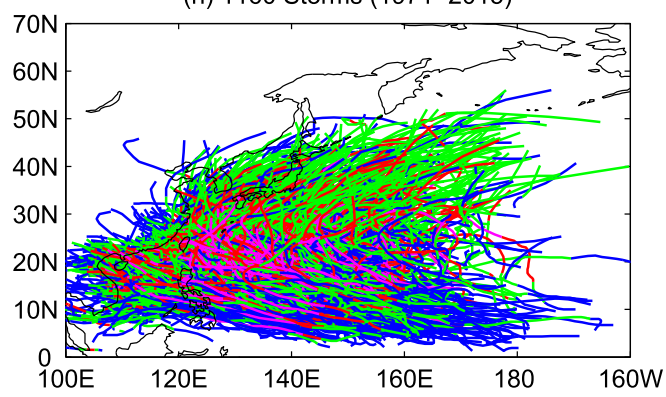

FIG. 11. Observed TC tracks for the period 1971-2015 from clusters (a) A, (b) B, (c) C, (d) D, (e) E, (f) F, and (g) G, and from (h) all clusters. Color denotes intensity, with tropical depressions in green, tropical storms in blue, hurricanes in red, and major hurricanes in magenta.

also be related to the placement of the northern edge of the TCM domain at $50^{\circ} \mathrm{N}$. Despite these issues, there is strong similarity among the simulated and observed tracks. This is not always the case, as some models simulate TC tracks that have no similarity to observations
(Camargo 2013; Nakamura et al. 2017). In summary, although the model tracks in the climatological simulation have some clear biases, there is overall similarity with the observed tracks. Therefore, we can use the TCM to analyze the response in simulated tracks to ENSO flavors. 
(a) Cluster A - 385 Storms, 70\% Landfall

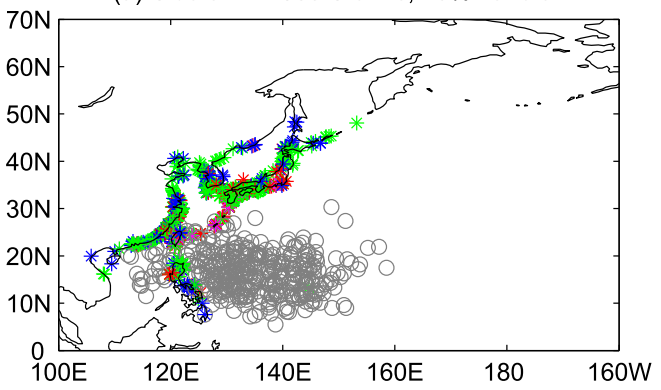

(c) Cluster C - 315 Storms, 17\% Landfall

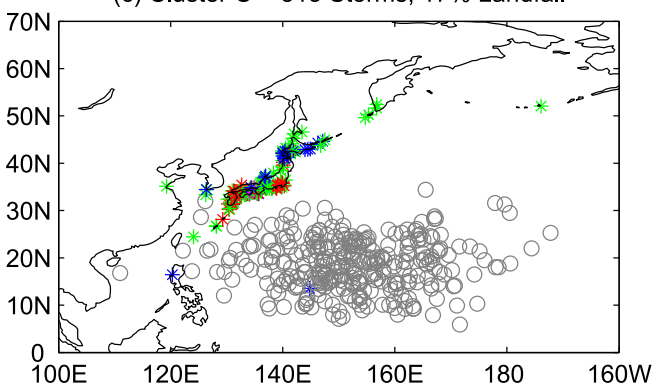

(e) Cluster E - 232 Storms, $48 \%$ Landfall

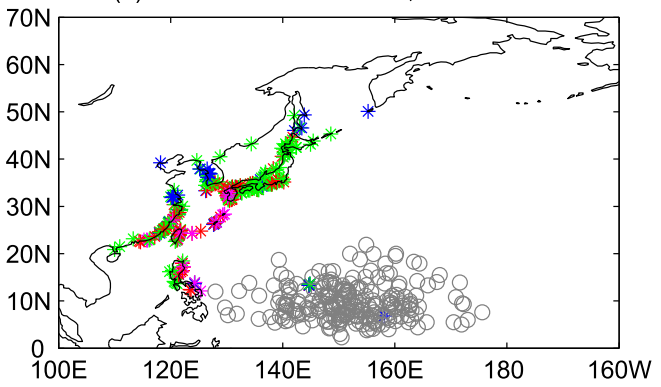

(g) Cluster G - 122 Storms, 22\% Landfall

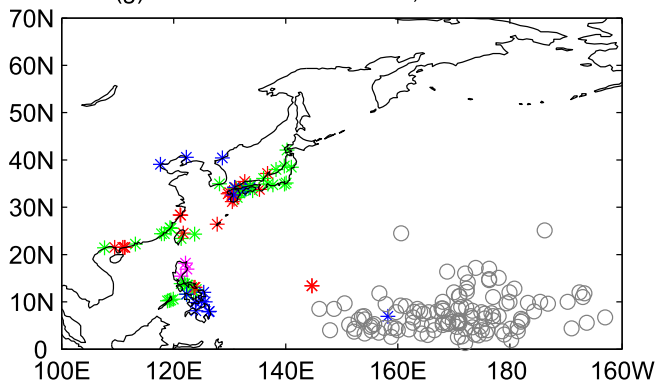

(b) Cluster B - 267 Storms, 87\% Landfall

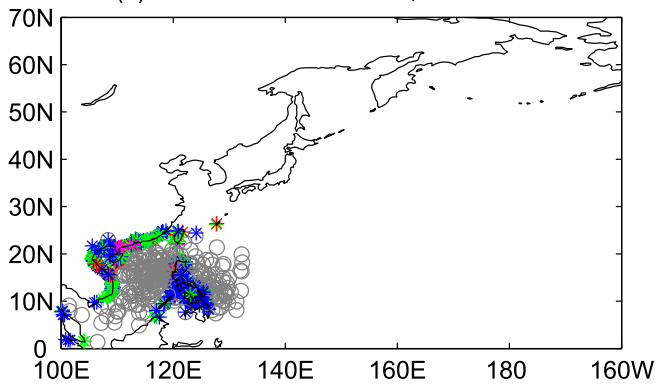

(d) Cluster D - 230 Storms, 86\% Landfall

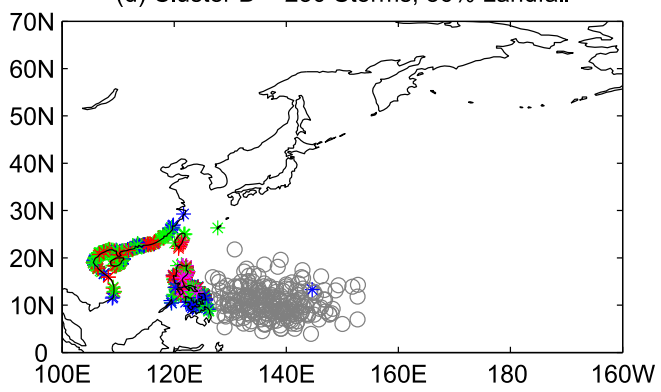

(f) Cluster F - 142 Storms, 75\% Landfall

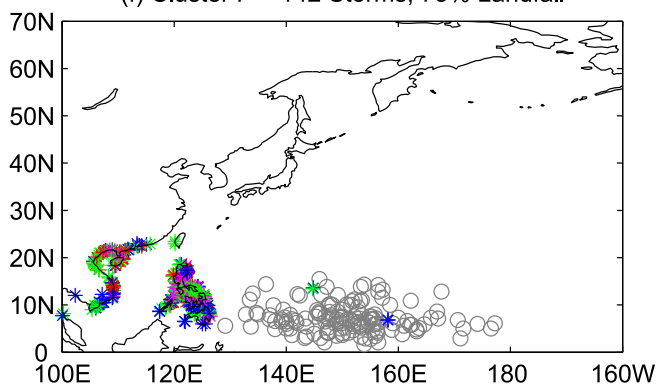

(h) 1693 Storms, $59 \%$ Landfall

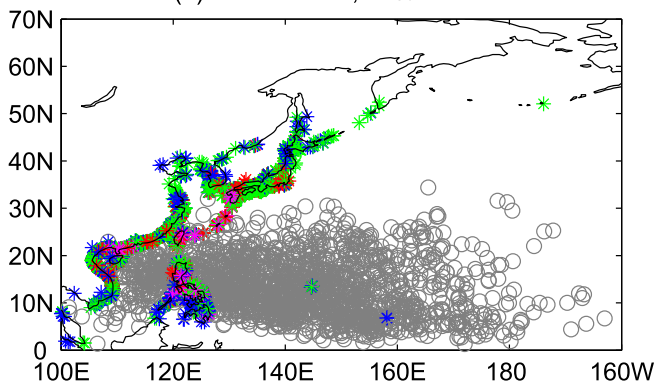

FIG. 12. First position (gray circles) and landfall locations (colored asterisks) for the full period 1950-2015 from clusters (a) A, (b) B, (c) C, (d) D, (e) E, (f) F, and (g) G, and from (h) all clusters. Color denotes intensity, as in Fig. 11, at landfall.

There is a significant difference in the total number of TCs among the ENSO-forced simulations, with a large increase in the number of storms in the CT, WP, and doubled WP El Niño simulations, compared with climatology simulations. Furthermore, the La Niña simulations contained fewer ensemble members than the three El Niño cases. Therefore, we believe that the most significant results are those for the differences in the percentages between different simulations, shown in Table 4. Table 4 and Fig. 14 indicate that there are statistically significant changes in the frequency of occurrence of specific type of tracks among the ENSO 
(a) Climatology Cluster A - 107 Storms

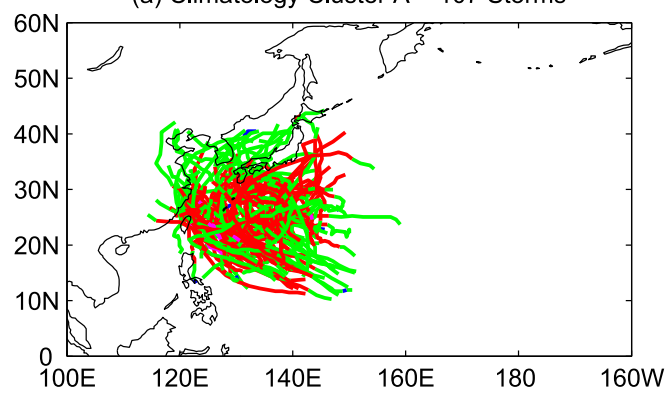

(c) Climatology Cluster C - 114 Storms

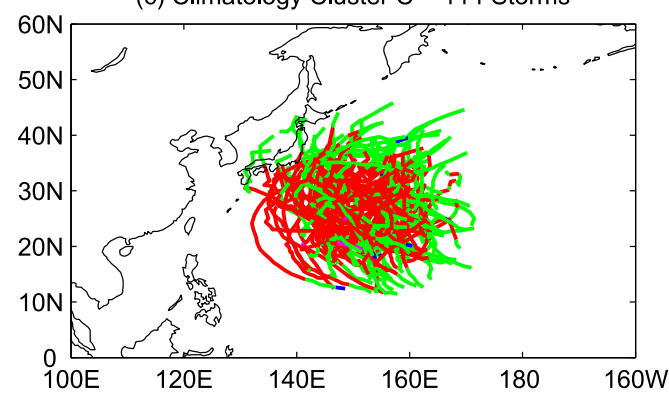

(e) Climatology Cluster E - 57 Storms

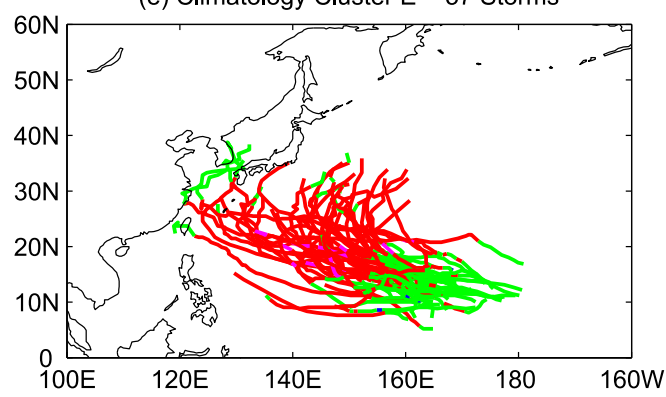

(g) Climatology Cluster G - 71 Storms

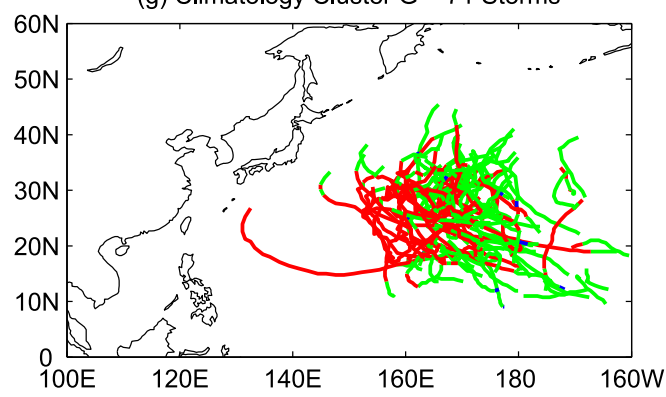

(b) Climatology Cluster B - 94 Storms

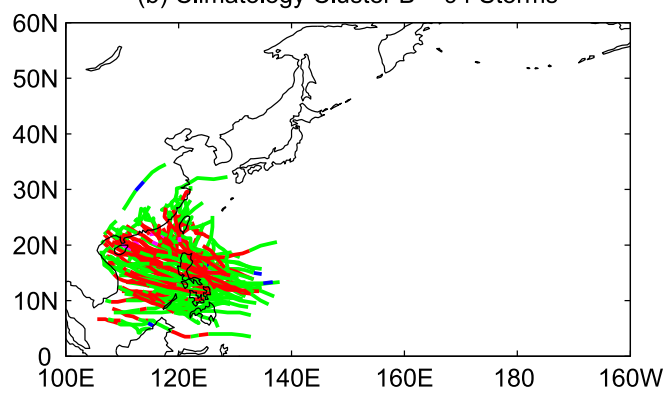

(d) Climatology Cluster D - 82 Storms

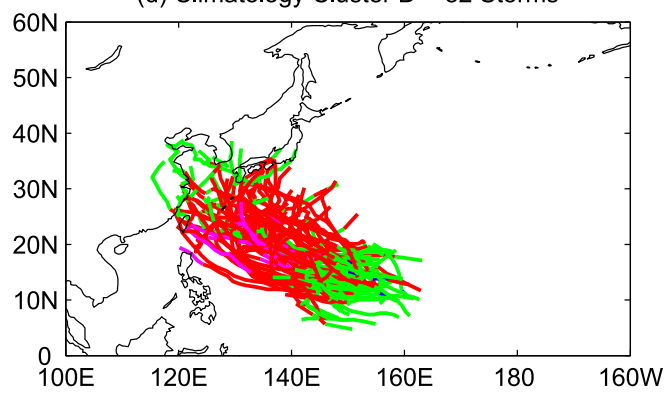

(f) Climatology Cluster F - 99 Storms

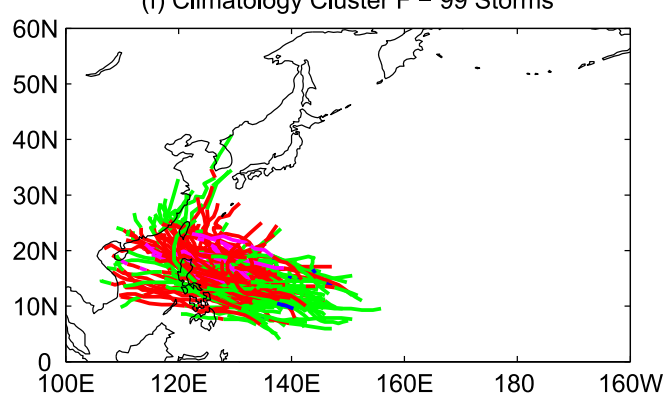

(h) Climatology - 624 Storms

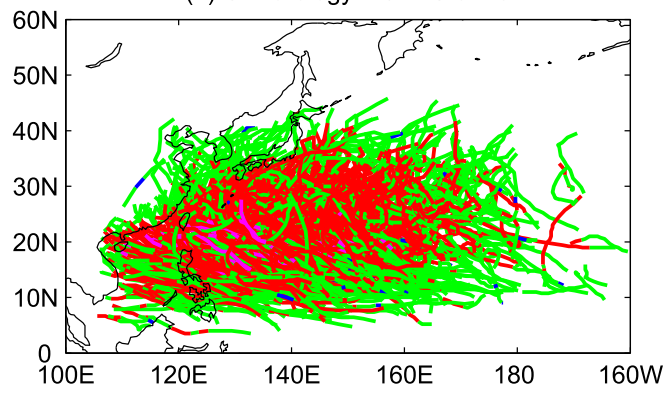

FIG. 13. TC tracks from the climatology simulation from clusters (a) A, (b) B, (c) C, (d) D, (e) E, (f) F, and (g) G, and from (h) all clusters. Color denotes intensity, as in Fig. 11.

scenarios. For instance, in the CT El Niño simulation there is an increase (decrease) in the occurrence of cluster C (D) tracks, compared with climatology. In contrast, when we compare the doubled WP El Niño simulation to climatology, there is a decrease in the occurrence of clusters B, C, and $\mathrm{F}$, and an increase in cluster E. Most interestingly, when comparing doubled WP El Niño and CT El Niño, there is a decrease in the occurrence of clusters $\mathrm{B}$ and $\mathrm{F}$ and increase in clusters $\mathrm{E}$ and $\mathrm{G}$.

These changes in cluster occurrence indicate a reduction of TC track types that occur near the Asian continent (clusters B and F) and an increase in the 


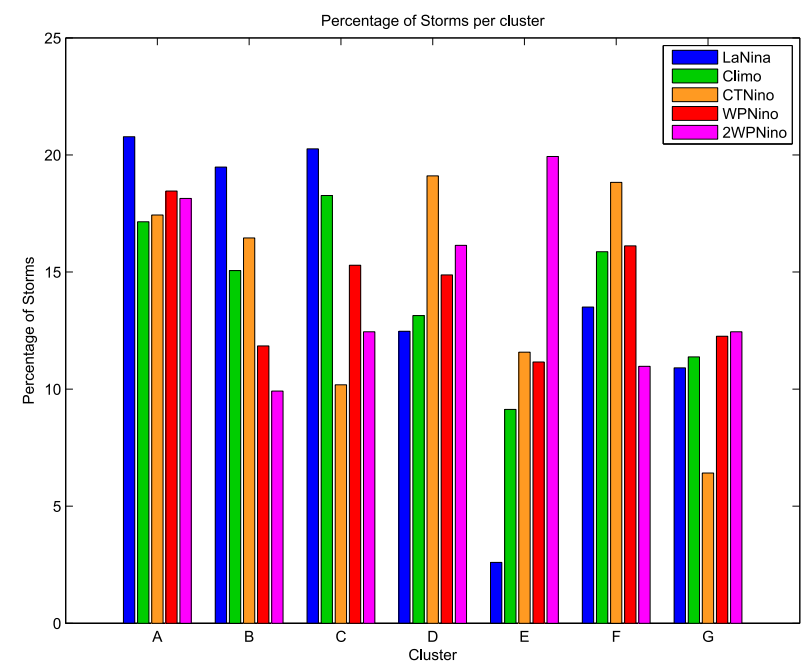

FIG. 14. Percentage of TCs in each cluster based on the TCM simulations.

occurrence of tracks in the eastern part of the basin (clusters $\mathrm{E}$ and $\mathrm{G}$ ), in the WP El Niño simulations compared with CT El Niño simulation (Fig. 15). Therefore, the known observed signal of a southeastward shift in genesis and tracks during El Niño events in the WNP compared with La Niña events (Chan 1985; Chia and Ropelewski 2002; Camargo et al. 2007c) is considerably amplified in the model when El Niño's maximum SST warming is located in the central Pacific (Table 3 and Fig. 16). In addition, it is well known that El Niño events tend to increase the occurrence of central North Pacific hurricane tracks, in particular in the vicinity of Hawaii (Chu 2004; Camargo et al. 2008). This has been observed even during weak El Niño events, such as the very active 2014 season, which had a central Pacific warming signature (Murakami et al. 2015b; Sobel et al. 2016). Therefore, this increase in the occurrence of TC tracks in the eastern part of the WNP basin with central Pacific SST warming could be seen as consistent with an increase in TC activity in the middle of the Pacific as a whole, as the basin division at the International Date Line is somewhat artificial. Indeed, eastern North Pacific $\mathrm{TC}$ activity increased substantially in response to WP El Niño, with greater TC activity increases in response to SST warming in the central, compared to eastern Pacific, for similar magnitudes of SST warming (Patricola et al. 2016).

\section{Conclusions}

ENSO is a major source of seasonal TC predictability in several ocean basins, including the WNP. However, in order to achieve the greatest improvement in seasonal TC prediction and future TC projections, it is necessary to understand how the relationship between ENSO and WNP TCs depends on the spatial characteristics of El
Niño. This is especially important given the observed and projected increase in frequency and intensity of warm pool El Niño events.

Here we investigated the response in basinwide WNP TC activity, as well as the spatial clustering of TC tracks, to two El Niño flavors (i.e., cold tongue and warm pool El Niño), using observations, tropical channel model simulations, and a sophisticated TC track clustering methodology. The climate model simulations were performed at a TC-permitting resolution of $27 \mathrm{~km}$. In addition to a control simulation that was forced with monthly varying climatological SST, we conducted mechanistic experiments with SST forcings characteristic of the strongest $10 \%$ of observed CT and WP El Niño and La Niña events, as well as a doubled WP El Niño forcing.

We found that both El Niño flavors enhance seasonal WNP TC activity in observations and climate model simulations. An important new finding is that the simulated WNP TC activity, including ACE and number of typhoons and intense typhoons, is more effectively enhanced by SST warming of the central, compared to the eastern, equatorial Pacific. This fits with the conclusion that warm pool El Niño is more effective at enhancing eastern Pacific and suppressing Atlantic TC activity, owing to warmer climatological SST and greater atmospheric instability in the central Pacific; that is, WP El Niño warms where it is already warm, whereas CT El Niño warms where the background SST is cool (Patricola et al. 2016).

El Niño also has a considerable influence on simulated TC tracks regionally, with a decrease in the percentage of TCs that generate near the Asian continent, and an increase in clusters that are dominated by TC genesis in the southeastern portion of the WNP with a northwestward track trajectory. This pattern of track cluster response is particularly strong in the doubled WP El Niño simulation and corresponds spatially with a pattern of reduced vertical wind shear.

In terms of seasonal prediction, the 22-member and 16-member ensemble of ENSO-forced simulations indicates that although internal atmospheric variability can generate a substantial range in the season total $\mathrm{ACE}( \pm 25 \%$ of the median $)$, the mean response in $\mathrm{ACE}$ to the ENSO forcings is sufficiently large to provide seasonal predictive value for WNP TC activity. Furthermore, extremely active WNP seasons are linked with El Niño in both observations and the climate model simulations. Internal atmospheric variability alone did not produce an extremely active WNP season in the climate model.

In addition to informing potential improvements in seasonal TC prediction, the findings presented here have several implications for climate change. First and most importantly, in order to reliably project future TC activity, coupled atmosphere-ocean global climate models 

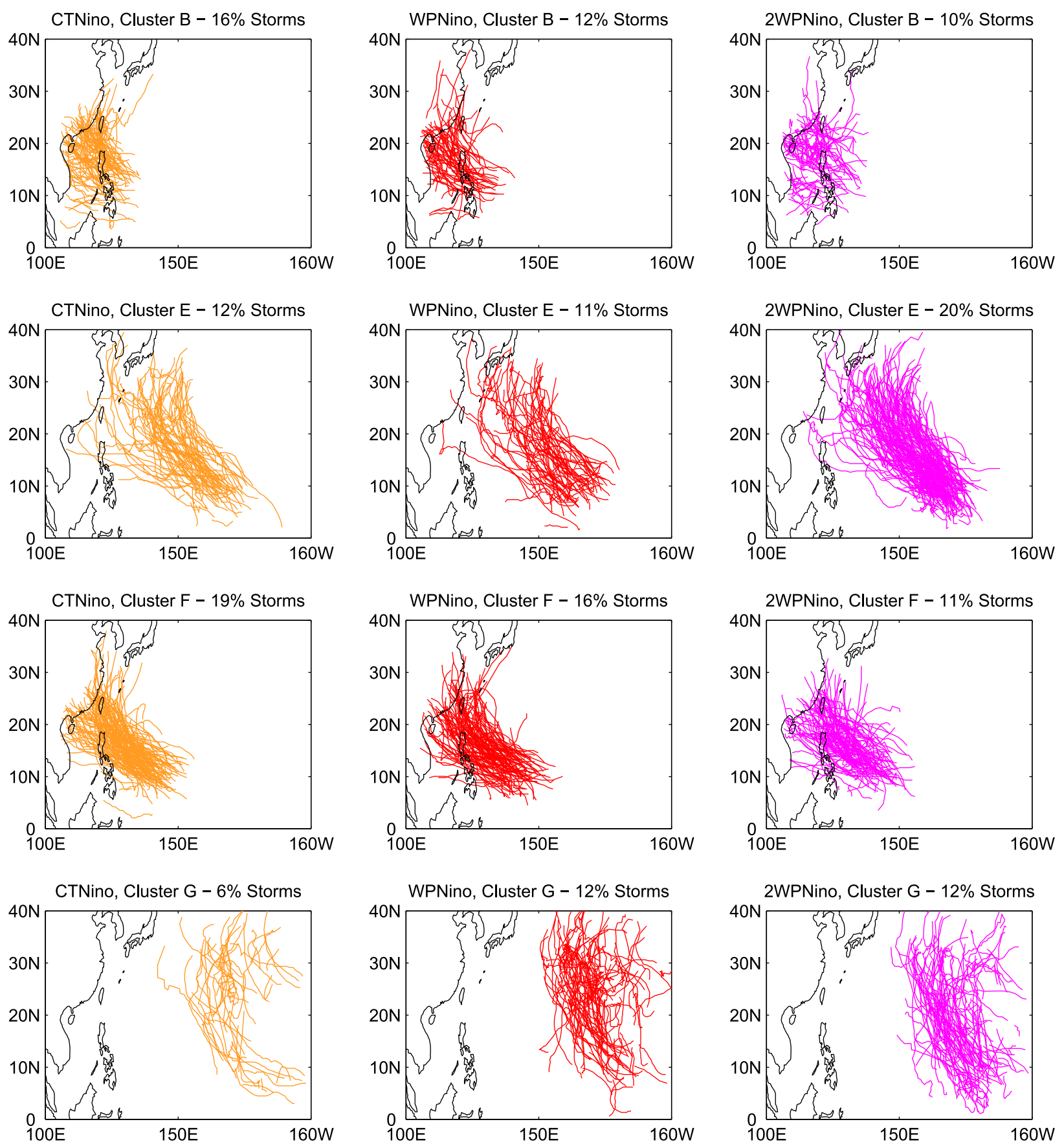

FIG. 15. TC tracks of model clusters B, E, F, and G, from the (left) CT El Niño, (center) WP El Niño, and (right) doubled WP El Niño simulations.

must be evaluated and improved to reliably represent the mean state of SST, as well as the frequency and spatial characteristics of El Niño, a topic that is the focus of ongoing essential research (e.g., Capotondi et al. 2015a,b; Richter 2015; Zuidema et al. 2016; references therein). Second, these results suggest that if warm pool El Niño events were to become more frequent and intense in the future, El Niño could become more effective at producing intense typhoons and consequently driving extremely active WNP TC seasons. This provides one of several pieces of information needed for reliable future TC projections, as, for example, the relationship between ENSO and TCs may change with a warming climate. Another important point is that future 

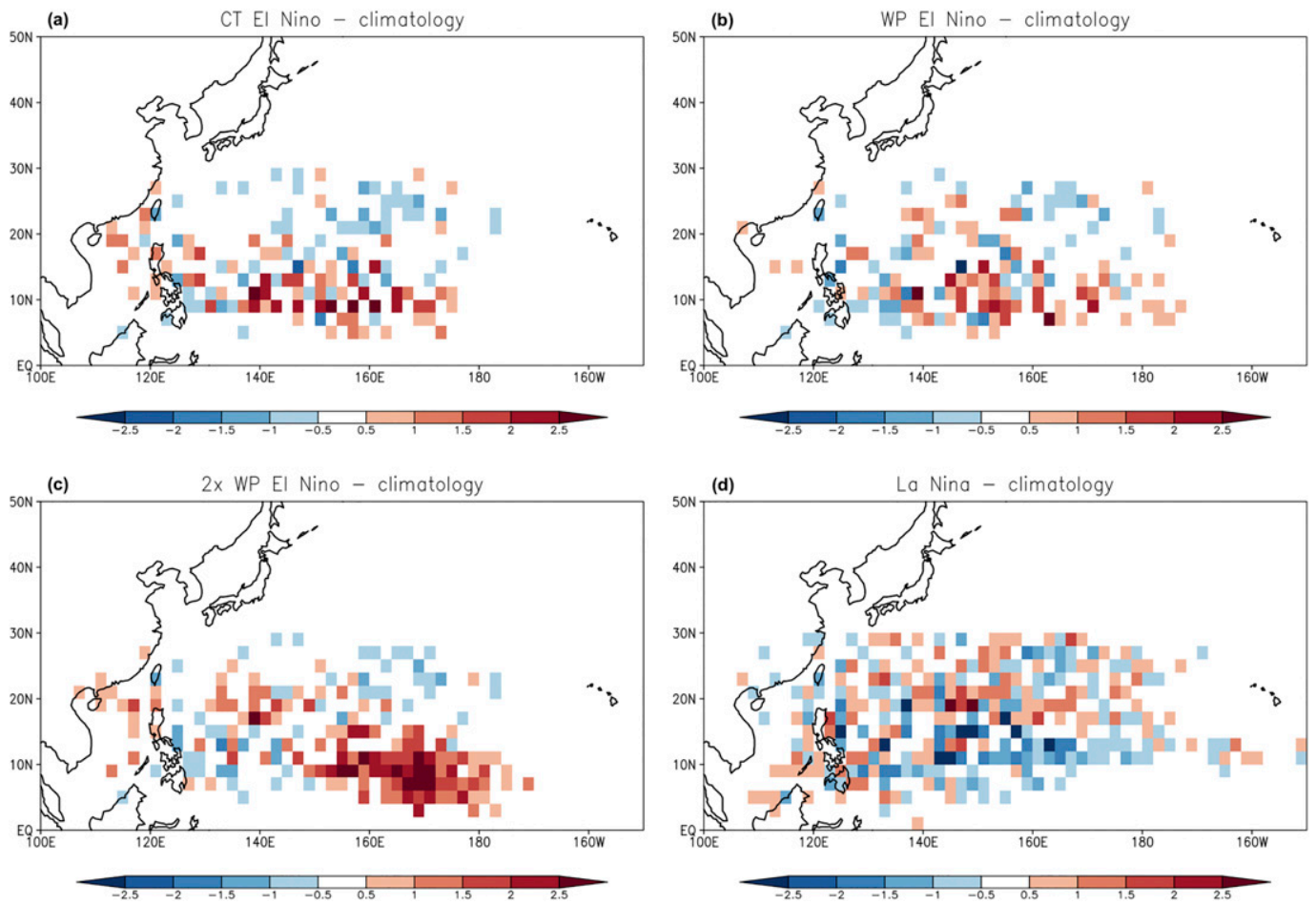

FIG. 16. TC genesis density (No. of TCs per 10 seasons) from the (a) CT El Niño, (b) WP El Niño, (c) doubled WP El Niño, and (d) La Niña simulations minus the climatology simulation.

projections of WNP TC activity include an eastward shift in storm tracks toward the central North Pacific (e.g., Nakamura et al. 2017), as well as an increase in the occurrence of TCs in the vicinity of Hawaii (Murakami et al. 2013). Given the relationship between warm pool El Niño and the eastward shift of WNP TC activity in the tropical channel model simulations, together with the eastward shifts in global model projections, it is important to examine if the projected changes in Pacific TC tracks are related to an increase in the occurrence of warm pool El Niño events in global climate model projections.

Acknowledgments. This material is based upon work supported by the U.S. Department of Energy, Office of Science, Office of Biological and Environmental Research, Climate and Environmental Sciences Division, Regional and Global Climate Modeling Program, under Award DEAC02-05CH11231. S. J. C. acknowledges support of National Oceanic and Atmospheric Administration (NOAA) Grants NA15OAR43100095 and NA16OAR4310079. P. J. K. acknowledges grant support from the G. Unger Vetlesen Foundation. P. C. acknowledges support of National Science Foundation Grants AGS-1067937 and AGS-1347808 and NOAA Grant NA11OAR4310154, as well as China's National Basic Research Priorities Programmer (2013CB956204) and the Natural Science Foundation of
China (41222037 and 41221063). High-performance computing resources provided by the Extreme Science and Engineering Discovery Environment (XSEDE), which is supported by National Science Foundation Grant ACI-1053575. Simulations were performed at the Texas Advanced Computing Center (TACC) at The University of Texas at Austin and the Texas A\&M Supercomputing Facility. Climate model output available on the Ranch archive system at TACC. The AMO index is available online at https://www.esrl.noaa.gov/psd/ data/timeseries/AMO/. The PDO index is available online at http://research.jisao.washington.edu/pdo/PDO. latest.txt. The El Niño indices are available online at http:// www.cpc.ncep.noaa.gov/data/indices/ersst4.nino.mth.8110.ascii. The authors thank Dr. Sumant Nigam and two anonymous reviewers for their constructive comments that helped improve the manuscript.

\section{REFERENCES}

Alexander, M. A., D. J. Vimont, P. Chang, and J. D. Scott, 2010: The impact of extratropical atmospheric variability on ENSO: Testing the seasonal footprinting mechanism using coupled model experiments. J. Climate, 23, 2885-2901, https://doi.org/ 10.1175/2010JCLI3205.1.

Ashok, K., S. K. Behera, S. A. Rao, H. Weng, and T. Yamagata, 2007: El Niño Modoki and its possible teleconnection. 
J. Geophys. Res., 112, C11007, https://doi.org/10.1029/ 2006JC003798.

Bell, G. D., and Coauthors, 2000: Climate assessment for 1999. Bull. Amer. Meteor. Soc., 81 (6), S1-S50, https://doi.org/ 10.1175/1520-0477(2000)81[s1:CAF]2.0.CO;2.

Boudreault, M., L.-P. Caron, and S. J. Camargo, 2017: Reanalysis of climate influences on Atlantic tropical cyclone activity using cluster analysis. J. Geophys. Res. Atmos., 122, 4258-4280, https://doi.org/10.1002/2016JD026103.

Bove, M. C., J. B. Elsner, C. W. Landsea, X. Niu, and J. J. O'Brien, 1998: Effect of El Niño on U.S. landfalling hurricanes, revisited. Bull. Amer. Meteor. Soc., 79, 2477-2482, https://doi.org/10.1175/1520-0477(1998)079<2477: EOENOO $>2.0 . \mathrm{CO} ; 2$.

Camargo, S. J., 2013: Global and regional aspects of tropical cyclone activity in the CMIP5 models. J. Climate, 26, 9880-9902, https://doi.org/10.1175/JCLI-D-12-00549.1.

, 2016: Tropical cyclones, western North Pacific basin [in "State of the Climate in 2015"']. Bull. Amer. Meteor. Soc., 97 (8), S110S114, https://doi.org/10.1175/2016BAMSStateoftheClimate.1.

—_, and S. E. Zebiak, 2002: Improving the detection and tracking of tropical cyclones in atmospheric general circulation models. Wea. Forecasting, 17, 1152-1162, https://doi.org/ 10.1175/1520-0434(2002)017<1152:ITDATO > 2.0.CO;2.

_- and A. H. Sobel, 2005: Western North Pacific tropical cyclone intensity and ENSO. J. Climate, 18, 2996-3006, https://doi.org/ 10.1175/JCLI3457.1.

_ Wiley Interdiscip. Rev.: Climate Change, 7, 211-237, https:// doi.org/10.1002/wcc.373.

— A. W. Robertson, S. J. Gaffney, P. Smyth, and M. Ghil, 2007a: Cluster analysis of typhoon tracks. Part I: General properties. J. Climate, 20, 3635-3653, https://doi.org/10.1175/JCLI4188.1.

,,,,---- and,$- 2007 \mathrm{~b}$ : Cluster analysis of typhoon tracks. Part II: Large-scale circulation and ENSO. J. Climate, 20, 3654-3676, https://doi.org/10.1175/JCLI4203.1.

—, K. A. Emanuel, and A. H. Sobel, 2007c: Use of a genesis potential index to diagnose ENSO effects on tropical cyclone genesis. J. Climate, 20, 4819-4834, https://doi.org/10.1175/ JCLI4282.1.

— A. W. Robertson, A. G. Barnston, and M. Ghil, 2008: Clustering of eastern North Pacific tropical cyclone tracks: ENSO and MJO effects. Geochem. Geophys. Geosyst., 9, Q06V05, https://doi.org/10.1029/2007GC001861.

Capotondi, A., and Coauthors, 2015a: Understanding ENSO diversity. Bull. Amer. Meteor. Soc., 96, 921-938, https://doi.org/ 10.1175/BAMS-D-13-00117.1.

_ , Y.-G. Ham, A. Wittenberg, and J.-S. Kug, 2015b: Climate model biases and El Niño Southern Oscillation (ENSO) simulation. US CLIVAR Variations, No. 13, U.S. CLIVAR Project Office, Washington, DC, 21-25.

Caron, L.-P., M. Boudreault, and S. J. Camargo, 2015: On the variability and predictability of eastern North Pacific tropical cyclone activity. J. Climate, 28, 9678-9696, https://doi.org/ 10.1175/JCLI-D-15-0377.1.

Chan, J. C. L., 1985: Tropical cyclone activity in the northwest Pacific in relation to the $\mathrm{El} \mathrm{Niño/Southern} \mathrm{Oscillation}$ phenomenon. Mon. Wea. Rev., 113, 599-606, https://doi.org/ 10.1175/1520-0493(1985)113<0599:TCAITN > 2.0.CO;2. ,2000: Tropical cyclone activity over the western North Pacific associated with El Niño and La Niña events. J. Climate, 13, 2960-2972, https://doi.org/10.1175/1520-0442(2000)013<2960: TCAOTW $>2.0 . \mathrm{CO} ; 2$.
_ 2005: Interannual and interdecadal variations of tropical cyclone activity over the western North Pacific. Meteor. Atmos. Phys., 89, 143-152, https://doi.org/10.1007/s00703-005-0126-y.

_ , and C. K. M. Yip, 2003: Interannual variations of tropical cyclone size over the western North Pacific. Geophys. Res. Lett., 30, 2267, https://doi.org/10.1029/2003GL018522.

Chand, S. S., J. L. McBride, K. J. Tory, M. C. Wheeler, and K. J. E. Walsh, 2013: Impact of different ENSO regimes on southwest Pacific tropical cyclones. J. Climate, 26, 600-608, https://doi.org/10.1175/JCLI-D-12-00114.1.

- K. J. Tory, H. Ye, and K. J. E. Walsh, 2017: Projected increase in El Niño-driven tropical cyclone frequency in the Pacific. Nat. Climate Change, 7, 123-127, https://doi.org/10.1038/ nclimate3181.

Chen, G., and C.-Y. Tam, 2010: Different impacts of Pacific Ocean warming on tropical cyclone frequency over the western North Pacific. Geophys. Res. Lett., 37, L01803, https://doi.org/ 10.1029/2009GL041708.

Chen, T.-C., S.-P. Weng, N. Yamazaki, and S. Kiehne, 1998: Interannual variation in the tropical cyclone formation over the western North Pacific. Mon. Wea. Rev., 126, 1080-1090, https://doi.org/10.1175/1520-0493(1998)126<1080: IVITTC $>2.0 . \mathrm{CO} ; 2$.

Chia, H.-H., and C. F. Ropelewski, 2002: The interannual variability in the genesis location of tropical cyclones in the northwest Pacific. J. Climate, 15, 2934-2944, https://doi.org/ 10.1175/1520-0442(2002)015<2934:TIVITG >2.0.CO;2.

Chu, J.-H., C. R. Sampson, A. S. Levine, and E. Fukada, 2002: The Joint Typhoon Warning Center tropical cyclone besttracks, 1945-2000. NRL Tech. Rep. NRL/MR/7540-02-16, $22 \mathrm{pp}$.

Chu, P.-S., 2004: ENSO and tropical cyclone activity. Hurricanes and Typhoons: Past, Present, and Future, R. J. Murnane and K.-B. Liu, Eds., Columbia University Press, 297-332.

Colbert, A. J., B. J. Soden, and B. P. Kirtman, 2015: The impact of natural and anthropogenic climate change on western North Pacific tropical cyclone tracks. J. Climate, 28, 1806-1823, https://doi.org/10.1175/JCLI-D-14-00100.1.

Daloz, A. S., and Coauthors, 2015: Cluster analysis of explicitly and downscaled simulated North Atlantic tropical cyclone tracks. J. Climate, 28, 1333-1361, https://doi.org/10.1175/ JCLI-D-13-00646.1.

Gaffney, S. J., 2004: Probabilistic curve-aligned clustering and prediction with regression mixture models. Ph.D. dissertation, University of California, Irvine, $281 \mathrm{pp}$.

—, A. W. Robertson, P. Smyth, S. J. Camargo, and M. Ghil, 2007: Probabilistic clustering of extratropical cyclones using regression mixture models. Climate Dyn., 29, 423-440, https:// doi.org/10.1007/s00382-007-0235-z.

Gray, W. M., 1984: Atlantic seasonal hurricane frequency. Part I: El Niño and $30 \mathrm{mb}$ quasi-biennial oscillation influences. Mon. Wea. Rev., 112, 1649-1668, https://doi.org/10.1175/ 1520-0493(1984)112<1649:ASHFPI > 2.0.CO;2.

Guan, B., and S. Nigam, 2008: Pacific sea surface temperatures in the twentieth century: An evolution-centric analysis of variability and trend. J. Climate, 21, 2790-2809, https://doi.org/ 10.1175/2007JCLI2076.1.

Han, R., and Coauthors, 2016: An assessment of multimodel simulations for the variability of western North Pacific tropical cyclones and its association with ENSO. J. Climate, 29, 64016423, https://doi.org/10.1175/JCLI-D-15-0720.1.

Hong, C.-C., Y.-H. Li, T. Li, and M.-Y. Lee, 2011: Impacts of central Pacific and eastern Pacific El Niños on tropical cyclone 
tracks over the western North Pacific. Geophys. Res. Lett., 38 , L16712, https://doi.org/10.1029/2011GL048821.

Horn, M., and Coauthors, 2014: Tracking scheme dependence of simulated tropical cyclone response to idealized climate simulations. J. Climate, 27, 9197-9213, https://doi.org/ 10.1175/JCLI-D-14-00200.1.

Huang, B., and Coauthors, 2015: Extended Reconstructed Sea Surface Temperature version 4 (ERSST.v4). Part I: Upgrades and intercomparisons. J. Climate, 28, 911-930, https://doi.org/ 10.1175/JCLI-D-14-00006.1.

Jien, J. Y., W. A. Gough, and K. Butler, 2015: The influence of El Niño-Southern Oscillation on tropical cyclone activity in the eastern North Pacific basin. J. Climate, 28, 2459-2474, https:// doi.org/10.1175/JCLI-D-14-00248.1.

Jin, C.-S., C.-H. Ho, J.-H. Kim, D.-K. Lee, D.-H. Cha, and S.- W. Yeh, 2013: Critical role of northern off-equatorial sea surface temperature forcing associated with central Pacific El Niño in more frequent tropical cyclone movements toward East Asia. J. Climate, 26, 2534-2545, https://doi.org/10.1175/ JCLI-D-12-00287.1.

Jin, F.-F., J. Boucharel, and I.-I. Lin, 2014: Eastern Pacific tropical cyclones intensified by El Niño delivery of subsurface ocean heat. Nature, 516, 82-85, https://doi.org/ 10.1038/nature13958.

Kalnay, E., and Coauthors, 1996: The NCEP/NCAR 40-Year Reanalysis Project. Bull. Amer. Meteor. Soc., 77, 437-471, https://doi.org/10.1175/1520-0477(1996)077<0437:TNYRP >2.0. $\mathrm{CO} ; 2$.

Kanamitsu, M., W. Ebisuzaki, J. Woollen, S.-K. Yang, J. J. Hnilo, M. Fiorino, and G. L. Potter, 2002: NCEP-DOE AMIP-II Reanalysis (R-2). Bull. Amer. Meteor. Soc., 83, 1631-1643, https://doi.org/10.1175/BAMS-83-11-1631.

Kao, H.-Y, and J.-Y. Yu, 2009: Contrasting eastern-Pacific and central-Pacific types of ENSO. J. Climate, 22, 615-632, https:// doi.org/10.1175/2008JCLI2309.1.

Kerr, R. A., 2000: A North Atlantic climate pacemaker for the centuries. Science, 288, 1984-1985, https://doi.org/10.1126/ science.288.5473.1984.

Kim, H.-M., P. J. Webster, and J. A. Curry, 2011: Modulation of North Pacific tropical cyclone activity by three phases of ENSO. J. Climate, 24, 1839-1849, https://doi.org/10.1175/ 2010JCLI3939.1.

Kim, J.-S., S. T. Kim, L. Wang, X. Wang, and Y.-I. Moon, 2016: Tropical cyclone activity in the northwestern Pacific associated with decaying central Pacific El Niños. Stochastic Environ. Res. Risk Assess., 30, 1335-1345, https://doi.org/10.1007/ s00477-016-1256-0.

Kim, S. T., and J.-Y. Yu, 2012: The two types of ENSO in CMIP5 models. Geophys. Res. Lett., 39, L11704, https://doi.org/ 10.1029/2012GL052006.

Knapp, K. R., M. C. Kruk, D. H. Levinson, H. J. Diamond, and C. J. Neumann, 2010: The International Best Track Archive for Climate Stewardship (IBTrACS). Bull. Amer. Meteor. Soc., 91, 363-376, https://doi.org/10.1175/2009BAMS2755.1.

Kossin, J. P., S. J. Camargo, and M. Sitkowski, 2010: Climate modulation of North Atlantic hurricane tracks. J. Climate, 23, 3057-3076, https://doi.org/10.1175/2010JCLI3497.1.

_ , K. A. Emanuel, and S. J. Camargo, 2016: Past and projected changes in western North Pacific tropical cyclone exposure. J. Climate, 29, 5725-5739, https://doi.org/10.1175/ JCLI-D-16-0076.1.

Kozar, M. E., M. E. Mann, S. J. Camargo, J. P. Kossin, and J. L. Evans, 2012: Stratified statistical models of North
Atlantic basin-wide and regional tropical cyclone counts. J. Geophys. Res., 117, D18103, https://doi.org/10.1029/ 2011JD017170.

Kug, J.-S., F.-F. Jin, and S.-I. An, 2009: Two types of El Niño Events: Cold tongue El Niño and warm pool El Niño. J. Climate, 22, 1499-1515, https://doi.org/10.1175/2008JCLI2624.1.

Lee, T., and M. J. McPhaden, 2010: Increasing intensity of El Niño in the central-equatorial Pacific. Geophys. Res. Lett., 37, L14603, https://doi.org/10.1029/2010GL044007.

Li, C., and C. Wang, 2014: Simulated impacts of two types of ENSO events on tropical cyclone activity in the western North Pacific: Large-scale atmospheric response. Climate Dyn., 42, 2727-2743, https://doi.org/10.1007/s00382-013-1999-y.

Li, T., M. Kwon, M. Zhao, J.-S. Kug, J.-J. Luo, and W. Yu, 2010: Global warming shifts Pacific tropical cyclone location. Geophys. Res. Lett., 37, L21804, https://doi.org/10.1029/ 2010GL045124.

Mantua, N. J., S. R. Hare, Y. Zhang, J. M. Wallace, and R. C. Francis, 1997: A Pacific interdecadal climate oscillation with impacts on salmon production. Bull. Amer. Meteor. Soc., 78, 1069-1079, https://doi.org/10.1175/ 1520-0477(1997)078<1069:APICOW>2.0.CO;2.

Mei, W., S.-P. Xie, M. Zhao, and Y. Wang, 2015: Forced and internal variability of tropical cyclone track density in the western North Pacific. J. Climate, 28, 143-167, https://doi.org/ 10.1175/JCLI-D-14-00164.1.

Mori, M., and Coauthors, 2013: Hindcast prediction and nearfuture projection of tropical cyclone activity over the western North Pacific using CMIP5 near-term experiments with MIROC. J. Meteor. Soc. Japan, 91, 431-452, https://doi.org/ 10.2151/jmsj.2013-402.

Murakami, H., B. Wang, and A. Kitoh, 2011: Future change of western North Pacific typhoons: Projections by a $20-\mathrm{km}-\mathrm{mesh}$ global atmospheric model. J. Climate, 24, 1154-1169, https:// doi.org/10.1175/2010JCLI3723.1.

— , and Coauthors, 2012: Future changes in tropical cyclone activity projected by the new high-resolution MRI-AGCM. J. Climate, 25, 3237-3260, https://doi.org/10.1175/ JCLI-D-11-00415.1.

, B. Wang, T. Li, and A. Kitoh, 2013: Projected increase in tropical cyclones near Hawaii. Nat. Climate Change, 3, 749754, https://doi.org/10.1038/nclimate1890.

, G. A. Vecchi, T. L. Delworth, K. Paffendorf, L. Jia, R. Gudgel, and F. Zeng, 2015a: Investigating the influence of anthropogenic forcing and natural variability on the 2014 Hawaiian hurricane season [in "Explaining Extreme Events of 2014 from a Climate Perspective"']. Bull. Amer. Meteor. Soc., 96 (12), S115-S119, https://doi.org/10.1175/ BAMS-D-15-00119.1.

, and Coauthors, 2015b: Simulation and prediction of category 4 and 5 hurricanes in the high-resolution GFDL HiFLOR coupled climate model. J. Climate, 28, 9058-9079, https:// doi.org/10.1175/JCLI-D-15-0216.1.

Nakamura, J., and Coauthors, 2017: Western North Pacific tropical cyclone model tracks in present and future climates. J. Geophys. Res. Atmos., 122, 9721-9744, https://doi.org/ 10.1002/2017JD027007.

Nigam, S., and B. Guan, 2011: Atlantic tropical cyclones in the 20th century: Natural variability and secular change in cyclone count. Climate Dyn., 36, 2279-2293, https://doi.org/10.1007/ s00382-010-0908-x.

Patricola, C. M., P. Chang, and R. Saravanan, 2016: Degree of simulated suppression of Atlantic tropical cyclones modulated 
by flavour of El Niño. Nat. Geosci., 9, 155-160, https://doi.org/ 10.1038 /ngeo 2624.

_- R. Saravanan, and P. Chang, 2017: A teleconnection between Atlantic sea surface temperature and eastern and central North Pacific tropical cyclones. Geophys. Res. Lett., 44, 11671174, https://doi.org/10.1002/2016GL071965.

Pielke, R. A., Jr., and C. W. Landsea, 1999: La Niña, El Niño, and Atlantic hurricane damages in the United States. Bull. Amer. Meteor. Soc., 80, 2027-2033, https://doi.org/10.1175/ 1520-0477(1999)080<2027:LNAENO>2.0.CO;2.

Ralph, T. U., and W. A. Gough, 2009: The influence of sea surface temperature on eastern North Pacific tropical cyclone activity. Theor. Appl. Climatol., 95, 257-264, https://doi.org/10.1007/ s00704-008-0004-x.

Ramsay, H. A., S. J. Camargo, and D. Kim, 2012: Cluster analysis of tropical cyclone tracks in the Southern Hemisphere. Climate Dyn., 39, 897-917, https://doi.org/10.1007/ s00382-011-1225-8.

Rayner, N. A., D. E. Parker, E. B. Horton, C. K. Folland, L. V. Alexander, D. P. Rowell, E. C. Kent, and A. Kaplan, 2003: Global analyses of sea surface temperature, sea ice, and night marine air temperature since the late nineteenth century. J. Geophys. Res., 108, 4407, https://doi.org/10.1029/ 2002JD002670.

Richter, I., 2015: Climate model biases in the eastern tropical oceans: Causes, impacts and ways forward. Wiley Interdisp. Rev: Climate Change, 6, 345-358, https://doi.org/10.1002/ wcc.338.

Roberts, M. J., and Coauthors, 2015: Tropical cyclones in the UPSCALE ensemble of high-resolution global climate models. J. Climate, 28, 574-596, https://doi.org/10.1175/ JCLI-D-14-00131.1.

Skamarock, W. C., and Coauthors, 2008: A description of the Advanced Research WRF version 3. NCAR Tech. Note NCAR/TN-475+STR, 113 pp., http://dx.doi.org/10.5065/ D68S4MVH.

Smirnov, D., and D. J. Vimont, 2012: Extratropical forcing of tropical Atlantic variability during the boreal summer and fall. J. Climate, 25, 2056-2076, https://doi.org/10.1175/ JCLI-D-11-00104.1.

Smith, S. R., J. Brolley, J. J. O'Brien, and C. A. Tartaglione, 2007: ENSO's impact on regional U.S. hurricane activity. J. Climate, 20, 1404-1414, https://doi.org/10.1175/JCLI4063.1.

Sobel, A. H., S. J. Camargo, A. G. Barnston, and M. K. Tippett, 2016: Northern Hemisphere tropical cyclones during the quasi-El Niño of late 2014. Nat. Hazards, 83, 1717-1729, https://doi.org/10.1007/s11069-016-2389-7.

Takahashi, K., A. Montecinos, K. Goubanova, and B. Dewitte, 2011: ENSO regimes: Reinterpreting the canonical and Modoki El Niño. Geophys. Res. Lett., 38, L10704, https:// doi.org/10.1029/2011GL047364.

Walsh, K., 1997: Objective detection of tropical cyclones in highresolution analyses. Mon. Wea. Rev., 125, 1767-1779, https:// doi.org/10.1175/1520-0493(1997)125<1767:ODOTCI>2.0.CO;2.

Wang, C., and X. Wang, 2013: Classifying El Niño Modoki I and II by different impacts on rainfall in southern China and typhoon tracks. J. Climate, 26, 1322-1338, https://doi.org/10.1175/ JCLI-D-12-00107.1.

, C. Li, M. Mu, and W. Duan, 2013: Seasonal modulations of different impacts of two types of ENSO events on tropical cyclone activity in the western North Pacific. Climate Dyn., 40, 2887-2902, https://doi.org/10.1007/s00382-012-1434-9.

Whitney, L. D., and J. S. Hobgood, 1997: The relationship between sea surface temperatures and maximum intensities of tropical cyclones in the eastern North Pacific Ocean. J. Climate, 10, 2921-2930, https://doi.org/10.1175/1520-0442(1997)010<2921: TRBSST $>2.0 . \mathrm{CO} ; 2$.

Wu, L., and Coauthors, 2014: Simulations of the present and latetwenty-first-century western North Pacific tropical cyclone activity using a regional model. J. Climate, 27, 3405-3424, https://doi.org/10.1175/JCLI-D-12-00830.1.

- H. Zhang, J.-M. Chen, and T. Feng, 2018: Impact of two types of El Niño on tropical cyclones over the western North Pacific: Sensitivity to location and intensity of Pacific warming. J. Climate, 31, 1725-1742, https://doi.org/10.1175/ JCLI-D-17-0298.1.

Wu, M. C., W. L. Chang, and W. M. Leung, 2004: Impacts of El Niño-Southern Oscillation events on tropical cyclone landfalling activity in the western North Pacific. J. Climate, 17, 1419-1428, https://doi.org/10.1175/1520-0442(2004)017<1419: IOENOE $>2.0 . \mathrm{CO} ; 2$.

Xu, S., and F. Huang, 2015: Impacts of the two types of El Niño on Pacific tropical cyclone activity. J. Ocean Univ. China, 14, 191198, https://doi.org/10.1007/s11802-015-2421-7.

Yeh, S.-W., J.-S. Kug, B. Dewitte, M.-H. Kwon, B. P. Kirtman, and F.-F. Jin, 2009: El Niño in a changing climate. Nature, $\mathbf{4 6 1}$, 511-514, https://doi.org/10.1038/nature08316.

Yokoi, S., Y. N. Takayabu, and H. Murakami, 2013: Attribution of projected future changes in tropical cyclone passage frequency over the western North Pacific. J. Climate, 26, 4096-4111, https://doi.org/10.1175/JCLI-D-12-00218.1.

Zhang, G., Z. Wang, T. J. Dunkerton, M. S. Peng, and G. Magnusdottir, 2016: Extratropical impacts on Atlantic tropical cyclone activity. J. Atmos. Sci., 73, 1401-1418, https:// doi.org/10.1175/JAS-D-15-0154.1.

Zhang, W., H.-F. Graf, Y. Leung, and M. Herzog, 2012: Different El Niño types and tropical cyclone landfall in East Asia. J. Climate, 25, 6510-6523, https://doi.org/10.1175/ JCLI-D-11-00488.1.

_ Y Y. Leung, and K. Fraedrich, 2015: Different El Niño types and intense typhoons in the western North Pacific. Climate Dyn., 44, 2965-2977, https://doi.org/10.1007/s00382-014-2446-4.

Zhao, H., 2016: A downscaling technique to simulate changes in western North Pacific tropical cyclone activity between two types of El Niño events. Theor. Appl. Climatol., 123, 487-501, https://doi.org/10.1007/s00704-015-1374-5.

Zhao, M., and I. M. Held, 2012: TC-permitting GCM simulations of hurricane frequency response to sea surface temperature anomalies projected for the late-twenty-first century. J. Climate, 25, 2995-3009, https://doi.org/10.1175/ JCLI-D-11-00313.1.

Zheng, Z.-W., I.-I. Lin, B. Wang, H.-C. Huang, and C.-H. Chen, 2015: A long neglected damper in the El Niño-typhoon relationship: A 'Gaia-like' process. Sci. Rep., 5, 11103, https:/ doi.org/10.1038/srep11103.

Zuidema, P., and Coauthors, 2016: Challenges and Prospects for reducing coupled climate model SST biases in the eastern tropical Atlantic and Pacific Oceans: The U.S. CLIVAR Eastern Tropical Oceans Synthesis Working Group. Bull. Amer. Meteor. Soc., 97, 2305-2328, https://doi.org/10.1175/ BAMS-D-15-00274.1. 